\title{
Osmanlı Matbuatında Acemler: Şirket-i Sahafiye-i İraniye
}

Filiz Diğıroğlu*

'Ajams in Ottoman Printing: Iranian Book Company (Şirket-i Sahafiye-i Iraniye)

Abstract - After the second half of the 19th century, as the printing in Ottoman Empire became widespread, the number of private printing houses increased and many new actors entered into the Ottoman printing market. Iranian entrepreneurs called Acem Basmacılar/Kitapçılar ('Ajam Printers/booksellers) were important actors of this market. Some of the printers and booksellers came together to establish companies. Şirket-i Sahafiye-i Iraniye (Iranian Book Company), was one of these companies and established by Iranian printers and bibliopoles operating in Istanbul to publish cheaply. It distinguished from other companies because of being a pioneer company in the Ottoman printing history and marked a quarter century in Ottoman printing. Contrary to its place in the Ottoman printing history, this company hasn't been quested independantly until now. This paper aims to discuss the establishment of the company, the identities and professions of the founders and partners of the company, the place of the print, bookstores, activities of the company, publication categories, publication policy, reader profile and the relationship of the company with the Ottoman official authorities. The paper concentrates especially on the relations of the company with censor mechanism of the Abdülhamid II Era and it will also try to answer the question that whether the Iranian identiy of the founders of the company affected the publication policy.

Keywords: Ottoman, 'Ajams/Iranians, printing press, shirket-i sahafiye bookseller.

\section{Giriş}

Osmanlı'da yayıncılık faaliyeti XIX. yüzyıl boyunca hızlı bir gelişim gösterdi ve Osmanlı kitap piyasasında matbu kitaplar basıp satan bir sektör haline geldi.

* Marmara Üniversitesi. 
1839 öncesinde Osmanlı Türkçesiyle 439 eser yayınlanmışken, 1876 sonrasında yirmi yıldan az bir sürede 3000'in üzerinde eser basılmışır. ${ }^{1}$ Tanzimat döneminde vilayet matbaalarının devreye girmesiyle birlikte devletin resmi matbu ağı en ücra yerlere kadar ulaşabilir hale gelmiştir. İstanbul ve taşrada gelecek vaadeden bu saha Ermeniler ve Rumlar başta olmak üzere gayrımüslim ve müslüman birçok Osmanlı tebasına geçim kaynağı olmuştur. Farklı etnik ve dini kimliklere sahip birçok özel işletmeye misyoner matbaaları ya da ecnebi matbaaları da eklenince Osmanlı matbuat aleminin aktörleri daha belirgin hale gelmiştir. Matbuatın bu yeni yaygınlık düzeyine erişmesindeki en önemli etken, bir yandan kağıt ve baskı maliyetlerinin düşmesi, bir yandan da daha güvenilir ve hızlı bir posta hizmetinin gelişmesi sayesinde yayınların fiyatlarının aşağı çekilebilmesiydi. ${ }^{2}$ Isste bu tablonun en belirgin figürlerinden 'Acem basmacılar/kitapçılar' da denilen İranlı müteşebbislerin bu alandaki rolü ve Osmanlı okuryazarlığındaki yeri yeterince ele alınmış değildir. ${ }^{3}$ Osmanlı matbuatında görülen bir diğer gelişme ise neşriyat piyasasında müstakil matbaa ve kitapçıların güçlerini birleştirerek şirketleşmeye gitmeleridir ki bu mevzu da hakettiği oranda akademik çalışmaya konu olmuş değildir. ${ }^{4}$ Şirket-i Sahafiye-i İraniye, Osmanlı yayıncılık tarihinde

1 Benjamin Fortna, Geç Osmanlı ve Erken Cumhuriyet Dönemlerinde Okumayı Öğrenmek, çev. Mehmet Beşikçi, (İstanbul: Koç Üniversitesi Yayınları, 2013), s. 249.

2 Fortna, Geç Osmanli, s. 249.

3 Son dönem Osmanlı başkentindeki Acem matbaacı/kitapçları ve basını üzerine Güllü Yıldız ile birlikte yürüttüğümüz kapsamlı projenin bir ürünü olan bu makale, Dersaadet'teki Acem matbaa ve kitapçılara dair resmin bir parçasını oluşturmaktadır. Bu proje çerçevesinde elde edilen ilk bulgular 2013'ten beri çeşitli akademik platformlarda paylaşılmaktadır. Dığıroğlu ve Yıldız’n yayınlanan çalışmaları için bkz. Filiz Dığıroğlu, Dersaadet’te Bir Acem Kitapçı:

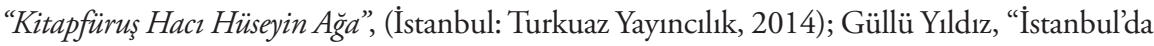
Bir Acem Matbaası: Kitapçı Tahir ve Ahter”, Osmanlı Araştırmaları, 50 (2017), s. 175-218.

4 Osmanlı matbuat aleminde bastıkları kitaplar ve artlarında bıraktıkları evraklar sayesinde bilinebilen ancak haklarında yeterince müstakil çalışma olmayan kitap şirketleri Şirket-i Sahafiye-i Osmaniye, Şirket-i Sahafiye-i İraniye, Tebaat ve Sahafiye Anonim Şirket-i Osmaniyesi, Kitapçılık ve Matbaacılık ve Gazetecilik Türk Anonim Şirketi, Ahmed İhsan ve Şürekası Matbaacılık Şirketi, İslam Alemi Matbuat Şirketi gibi kitapçılardır. Bu kitapçılar içinde Şirket-i Sahafiye-i Osmaniye dışındakiler hakkında henüz bir araştırma yapılmış değildir. Şirket-i Sahafiye-i Osmaniye hakkındaki kayda değer iki çalışma için bkz. Fatmagül Demirel, “Osmanlı'da Bir Kitap Şirketi: Şirket-i Sahafiye-i Osmaniye”, Müteferrika, 25 (2004), s. 89-97. Mehmet Ö. Alkan, “Osmanlı'nın Bütün Sahafları Birleşiniz! Şirket-i Sahafiye-i Osmaniye: Osmanlı Döneminde Sahaflar ve Yayınladıkları Kitaplar”, Müteferrika, 29 (2006), s. 3-44. 
bu tür şirketlere öncülük etmesi ve İstanbul'da yaşayan İranlı/Acem matbaacı/ sahaf esnafı tarafından kurulması bakımından diğerlerinden ayrılmaktadır. Dolayısıyla Osmanlı matbuat sektöründe rolleri tam olarak açığa kavuşturulamamış olan Acem matbaacıların Şirket-i Sahafiye-i İraniye tecrübesine odaklanmak hem matbuattaki Acem etkinliğini hem de sektördeki değişimleri anlamak için oldukça verimli olacaktır.

İstanbul'da faaliyet gösteren Acem/İranî matbaacıların kurdukları Şirket-i Sahafiye-i İraniye, Osmanlı matbuatında yaklaşık çeyrek asırlık bir dönemde faaliyette bulunmuştur. Bu çalışma, şu ana kadar hakkında müstakil bir çalışma yapılmamış olan Şirket-i Sahafiye-i İraniye'nin kuruluşu, kurucuların ve ortakların kimlikleri ile meslekleri, matbaanın yeri, kitap satış noktaları, şirketin faaliyetleri, ne tür eserler bastığı, yayın politikası, baskı tekniği, okur profili gibi noktaları ve şirketin Osmanlı resmi makamları ile ilişkilerini aydınlatmayı amaçlamaktadır. Osmanlı yayıncılığının gözle görülür bir ivme kazandığı II. Abdülhamid devrinde, Şirket-i Sahafiye-i İraniye’nin dönemin 'sansür' mekanizmalarıyla ilişkilerine özellikle değinecek olan bu makalenin, ana kaynağını Osmanlı Devleti'nin resmi belgeleri oluşturmaktadır. Bu bağlamda Başbakanlık Osmanlı Arşivi ve Meşihat Arşivi kaynakları kullanılacaktır. ${ }^{5}$ Şirketin faaliyetleri basılı kitaplar üzerinden takip edilebileceği için kütüphanelerdeki mevcut Şirket-i Sahafiye-i İraniye Matbaası'nda basılmış kitaplar incelenecektir. Çünkü basılan kitapların içerikleri ile müellifleri, şirketin yayın politikasını ve okur profilini anlamak için önemli ipuçlarını barındırmaktadır. Ayrıca şirket kurucularının 'Acem' kimliğinin yayın politikasında bir izdüşümü olup olmadığı tespit edilmeye çalışılacaktır.

\section{Şirket-i Sahafiye-i İraniye'nin Kuruluşu}

Osmanlı Devleti'nde XIX. yüzyılın ikinci yarısından itibaren matbaacılık yaygınlaşmış ve özel matbaaların sayısı hızla artmıştır. Artan matbaa sayısı

5 II. Abdülhamid dönemi matbuat denetim mekanizmasının iki ana unsuru olan Maarif Nezareti ve Dahiliye Nezareti’nin evrakları çalışmanın ana kaynağını oluşturmaktadır. Başbakanlık Osmanlı Arşivi'ndeki Maarif Nezareti bünyesindeki Teftiş ve Tercüme Encümeni ile Dahiliye Nezareti bünyesindeki Matbuat Dairesi'nin dosya usulü tasnifleri ve bu nezaretlerin Mektubi Kalemi'ndeki evraklar esas alınarak hazırlanmıştır. Yine kontrol mekanizmasının unsurları olan Zabtiye Nezareti ile Rusumat Emaneti evrakı da konu çerçevesinde taranmıştır. Şirket-i Sahafiye-i İraniye'nin mushaf ve dini yayıncılık faaliyetlerinde bulunması hasebiyle bir kısım evrakı, Meşihat Arşivi’nde dini eserleri ve Mushafları inceleyen Tedkik-i Mesahif-i Şerife ve Müellefat-1 Şer'iyye Dairesi'nin kayıtlarından elde edilmiştir. 
Osmanlı'da Tanzimat reformlarının ardından yaşanan siyasi, sosyal ve iktisadi alandaki birçok gelişme ile yakından bağlantılı olmakla beraber yaygın eğitimin gelişmesi ile doğrudan alakalıdır. Bu matbaalar içerisinde şirketleşmeyi başarmış iki kurum, Şirket-i Sahafiye-i Osmaniye ile Şirket-i Sahafiye-i İraniye’dir. Müslüman matbaacılar tarafından kurulan bu iki şirkete dair bilgiler oldukça azdır. Sınırlı Osmanlı matbuat tarihi literatüründe Şirket-i Sahafiye-i Osmaniye'nin kuruluş tarihi bile netleştirilememiştir. İsimlerinin çok benzer olması ve resmi evraklarda bazen kısaca Şirket-i Sahafiye olarak zikredilmeleri söz konusu şirketin hangisi olduğunu tespit etmede güçlük çıkarmaktadır. ${ }^{6}$

Osmanlı tebası müslüman sahaf/kitapçılara şirketleşme hususunda öncülük eden Acem matbaacı ve kitapçıların kurduğu Şirket-i Sahafiye-i İraniye, arşiv ve kütüphane kayıtlarında muhtelif şekillerde karşımıza çıkmaktadır: "Şirket-i Sahafiye-i İraniye", "Şirket-i İraniye", " "Şirket-i Sahafiye", "Matbaa-i Şirket-i İraniye", ${ }^{10}$ "Şirket-i İraniye Matbaası", ${ }^{11}$ "Şirket-i Sahafiye Matbaası", 12 "Şirket-i İraniye Destgahı", 13 "Matbaa-i İraniye",14 "İraniye Matbaası", 15 "Matbaa-i

6 Fatmagül Demirel'e göre Osmanlı tebası iki müslüman sahaf tarafından kurulan Şirket-i Sahafiye-i Osmaniye'nin kuruluşu tarihi 14 Nisan 1882'dir. Demirel, “Osmanlı'da Bir Kitap Şirketi”, s. 89. Daha sonra yapılan araştırmalarda ise sahaf şirketinin kuruluşu daha erken bir tarihe indirilmiştir. Bu çalışma 1882'den önce de böyle bir örgütlenme olduğu, "Şirket-i Sahafiye” adlı bir kurumun, 1874'den (H. 1291) itibaren bastığı kitaplardan söz etmektedir. Alkan, “Osmanlı’nın Bütün Sahafları Birleşiniz!”, s. 4. Aslında şirketin kuruluş tarihindeki müphemlik, Şirket-i Sahafiye ile Şirket-i Sahafiye-i Osmaniye’nin aynı ya da farklı şirketler olup olmadığı konusu ile doğrudan alakalı ve hala araştırmaya değer bir konudur. Kaldı ki Şirket-i Sahafiye olarak kayıtlarda geçen, Şirket-i Sahafiye-i İraniye de olabilir.

7 Türkiye Cumhuriyeti Cumhurbaşkanlığı Devlet Arşivleri Başkanlığı Osmanlı Arşivi (BOA), Dahiliye Nezareti Matbuat-1 Dahiliye Kalemi (DH. MDK) 278/98, Maarif Nezareti Telif ve Tercüme Dairesi (MF. TTD) 24/106.

8 BOA, Maarif Nezareti Mektubi Kalemi (MF. MKT) 147/69; MF. TTD 22/74, 49/92; DH. MDK $247 / 52$.

9 BOA, MF. MKT 509/22; MF. TTD 24/43, 24/57; Dahiliye Nezareti Mektubi Kalemi (DH. MKT) 1987/82.

10 M. Seyfettin Özege, Eski Harflerle Basılmış Türkçe Eserler Kataloğu, I-V, (İstanbul: Fatih Yayınevi Matbaası, 1971-1982), nr. 274.

11 BOA, DH. MDK 220/169; MF. MKT 147/69. Özege, nr. 975, 1145.

12 Özege, Eski Harflerle Basılmıs Türkçe Eserler Kataloğu, nr. 1354, 3870.

13 Özege, Eski Harflerle Basılmış Türkçe Eserler Kataloğu, nr. 4177.

14 Özege, Eski Harflerle Basılmış Türkçe Eserler Kataloğu, nr. 4979, 20566, 21252, 21253.

15 İlm-i Hâl, (İstanbul: İraniye Matbaası, 1304), 40 s.; Abdullah b. Eşref Rumi el-İzniki, Müzekkiyü’n-nüfus, (İstanbul: İrâniye Matbaası), 2 c., 359 s. 
Mahsusa-i İraniye". ${ }^{16}$ Kayıtlarda "Şirket-i Sahafiye" ve "Şirket-i Sahafiye Matbaası" şeklindeki ibareler, 'Validehan'daki' ya da 'İranlı/Acem basmacılar tarafından idare edilen', 'teba-i İraniyânın işlettiği' gibi ifadelerle tavsif edilmiyorsa söz konusu şirketle iltisak kurmak oldukça güçleşmekte hatta Osmanlı tebaası sahafların kurduğu şirketle karışma ihtimali artmaktadır. Bu ibarelere eklenecek farklı bir isimden de bahsedilmelidir. Şirket-i İraniye'nin 1310 yılında bastığı Sebatülacizin' in son sayfasında şirket müdürü sıfatıyla $\mathrm{Hacı}$ Abbas Ağa’nın verdiği ilanda "Şirket-i Hayriye-i İraniye" ismi zikredilmiştir. ${ }^{17}$

İstanbul'da faaliyet gösteren Acem/İranî matbaacıların daha ucuz neşriyat yapmak amacıyla bir araya gelerek kurdukları ve kitap şirketi olarak İstanbul'daki ilk oluşum büyük ihtimalle Şirket-i Sahafiye-i İraniye'dir. ${ }^{18}$ Maarif Salnamesi nde Şirket-i Sahafiye-i İraniye'nin kuruluş tarihi 1290/1873-74 olarak verilmektedir. ${ }^{19}$ Matbaa hakkında verilen diğer bilgiler Validehan'da bulunduğu, litografya usulu baskı yaptığı, Türkçe dışında bir lisanda eser ve resim basmadığı ile imtiyaz sahibinin Hacı Abbas Efendi olduğudur. ${ }^{20}$ Bu bilgilerin salnamenin (1316) aktüel bilgileri olduğu ve tüm bilgilerin kuruluş dönemini yansıtmadığını hatırlatmak gerekir.

Hisseli bir kumpanya olmasına rağmen Şirket-i Sahafiye-i İraniye'nin elimizde mukavelenamesi olmadığından şirketin hissedarlarına dair net bilgilere sahip değiliz. Hissedarlara dair elimizdeki kaynaklar, Ahter'deki şirket feshi ile ilgili ilan ve bu ilana hisse varislerinden birinin yaptığı itirazdır. Şirket-i Sahafiye-i

16 Özege, Eski Harflerle Basılmış Türkçe Eserler Kataloğu, nr. 11929, 13300.

17 Sebatül-Acizin, (İstanbul: Matbaa-i Şirket-i İraniye, 1310), s. 129.

18 Dedesi Acem kitapçı Hacı Hüseyin Ağa’yı Şirket-i İraniye’nin kurucusu olarak ifade eden Rıza Özden’in beyanı “...bir zaman sahafları bir araya getirtip cemiyet kurmuş ve müdürlüğünü yapmış. Daha sonra "Şirket-i Sahafiye-i İraniye isimli bir şirket kurmuş. Daha ucuz neşriyat yapmak teşebbüslerine girişmiş.” şeklindedir. Bkz. Dığıroğlu, Dersaadet'te Bir Acem Kitapçı, s. 35, 19-20. (vurgular yazara ait). Neden İranlılar kuruyor şirketi? Kendi tecrübeleri mi buna müsait?

19 Maarif Salnamesi, 1318/1900-1901, s. 924-925.

20 Maarif Salnamesi, 1316/1898-1899, s. 758-759. Litograf baskı yapılması ve resim basılmaması matbaanın sonraki gelişmelerinden biri olarak düşünülmeli ve salnamenin güncel bilgisi olarak anlaşılmalıdır. Zira kurulduğu yıllardaki taşbaskı ve resimli yayın faaliyetleri aşikardır. 1874 tarihli Ahmediye taşbaskıya, 1875 yılında basılan Kitab-ı Muhammediye ise hem taşbaskı hem de resimli baskıya iyi bir örnektir. Bkz. Ahmediye: Kitab-ı Mürşid-i Pend-i Ahmediye, (İstanbul: Matbaa-i Şirket-i İraniye, 1291/1874); Matbaa-i Şirket-i İraniye; Kitab-ı Muhammediye fî Kemalati'l-Ahmediye (İstanbul: Şirket-i İraniye Matbaası, 1292/1875). 
İraniye hissedarlarından merhum tüccar Hacı İbrahim Halil Efendi’nin oğlu İsmail Efendi'nin şirketin feshiyle ilgili Ahter'de çıan bir ilana itiraz ederek 29 Haziran 1895/17 Haziran 1311'de verdiği dilekçe, şirketin kuruluşuna ve ortaklarına dair kıymetli bilgiler içermektedir. Validehan'da kaliçe tüccarı olan babası Hacı İbrahim Halil Efendi'nin 1307/1890'daki vefatına kadar 23/40'lık hisse ile Şirket-i Sahafiye-i İraniye'nin en büyük hissedarı olduğunu ifade eder. Babasının vefatının ardından mirasın tamamının İran tebasından Mirza Şefi'ye geçirildiğinden yakınıp, haklarının korunmasını talep eder. İsmail Efendi dilekçesinde, şirket hisseleri 'gasbı'na dair 25 Haziran 1895'te Ahter'de yayınlanan 'şirket tefriki' ilanına atıf yapar. Bu ilana yapılan itirazda 25 yıldır aktif olarak yayıncılık yapan şirketten bahseder. Böylece Şirket-i İraniye’nin kuruluş tarihi, 1870’lere kadar indiği gibi en büyük hissedarın da Validehanlı bir tüccar olduğu ortaya çıkmaktadır. Dilekçede yer verilen Ahter'deki ilanda şirketin kurucusu ve müdürü olarak M. Tahir ile tahvildarı olarak Abbas isimleri görülmektedir. ${ }^{21}$ Şirket kurucusu olarak tanımlanan M. Tahir, İstanbul'daki Acem topluluğu içerisinde 'Kitapçı Tahir' olarak tanınan Muhammed Tahir Tebrizî olmalıdır. Tahir Efendi'nin 1876 Ocak'ında ilk sayısını yayınladığı Abter Gazetesi'nin sahibi ve daha sonrasında gazete ile aynı isimdeki matbaanın müdürü olduğu bilinmektedir. ${ }^{22} 1876$ 'da İstanbul'daki ilk ve en uzun soluklu Farsça gazeteyi yayınlamadan önce de Tahir Tebrizînnin matbaa ve kitap işleriyle uğraştı̆̆ 1 göz önünde bulundurulursa Ahter'den önceki faaliyetlerinin Validehan'daki Şirket-i İraniye matbaası olduğu rahatlıkla söylenebilir. Ayrıca Ahter'in Validehan'daki bir matbaada çıkarıldığı ve Ahter Matbaası'nın da başlangıçta bu handa yer aldığı hatırlatılmalıdır. Ne Ahter Matbaası'nın ne de Şirket-i Sahafiye-i İraniye Matbaası'nın,

21 İstanbul'daki ilk ve en uzun süreli neşriyatta bulunan Farsça gazete $A$ hter'deki şirketin feshiyle ilgili ilanın başlığı "İlan-1 Şirket-i Tabaat-i İraniye”dir. Bu ilanda "müessis ve müdir-i şirket-i mezbur Muhammed Tahir”, "tahvildar-1 şirket-i mezbur Hacı Abbas İrani” imzaları görülmektedir. Ancak şirketin en büyük hissedarının varisi sıfatıyla yaptığı itirazda İsmail Efendi, Tahir Efendi'yi 'müessis ve müdür-i şirket süsü takınan' ifadeleriyle suçlaması akla birkaç şeyi getiriyor: Birincisi başlangıçta Tahir Efendi'nin zannedildiği kadar etkin olmadığı, ikincisi büyük hissedar olarak şirket kuruluşunda sermayenin gücünü daha fazla öne çıkması gerektiği ya da babası Hacı İbrahim Halil Efendi'nin mirasının gasbında Tahir Efendi'nin payı olduğunu düşündüğü için hissi bir ifade kullanmayı tercih ettiğini düşündürtüyor. BOA, Şura-yı Devlet (ŞD), 2970/31, 27 M 1313/20 Temmuz 1895. Ahter Gazetesi'ndeki ilanı da kaynak gösteren Yıldız’n verdiği benzer bilgiler için bkz. Yıldız, "İstanbul'da Bir Acem Matbaası", s. 188, dn 62.

22 Tahir Efendi ve faaliyetlerine dair bkz. Yıldız, "İstanbul'da Bir Acem Matbaası", s. 175-207. 
İstanbul'daki Acemlerin merkezi konumundaki Validehan'da bulunması tesadüfi değildir. ${ }^{23}$

Maarif Nezareti, 18 Ocak 1873'te, bazı İranlıları ellerinde resmi senet olmadığı halde, Osmanlı Devleti'nden ruhsat alarak matbaa açmış olanlarla 'şirket akdi' yaparak, kitap yayıncılığı yaptıklarını Babıali'ye şikayet ediyordu. Bu İranlıların basımı yasak olsun olmasın birçok kitap ve risale yayınladıklarından bahsedilip, yasaklı yayınlar için haklarında gerekli cezai işlem uygulanması isteniyordu. ${ }^{24} \mathrm{Bu}$ evrakta kastedilen ticari oluşum Şirket-i İraniye olmalıdır. Çünkü Şirket-i İraniye adına basılan ilk kitabın baskı tarihi 1287/1870-71'dir. Üstelik İstanbul'daki Acem kitapçıların en önemli figürlerinden biri olan kitapçı Tahir [Tebrizî]'in, İstanbul'da 1279/1862-63'te ilk defa bir matbaa ruhsatı aldığı ve bir süre Rusya tebasından Hacı Abbas Kerimov ile ortaklık yürüttüğüne dair kendi beyanı bilinmektedir. ${ }^{25}$ Şirketin ilk kitabının baskı tarihi, kitapçı Tahir' in beyanı ve Maarif Nezareti şikayeti birlikte düşünüldüğünde, ruhsatlı matbaa açarak şirket akdi yapanın Tahir Tebrizî olma ihtimali artmaktadır. Her ne kadar 'Şirket-i İraniye hissedârânı' ve çalış̧anı İsmail Efendi, pederinden intikal eden şirket hisselerinin gasbında rolü olduğunu düşündüğü Tahir Efendi'yi 'müessis ve müdür-i şirket süsü takınan' ifadeleriyle suçlasa da en başından beri Tahir Efendi'nin şirket işlerinin içinde olduğu muhakkaktır. Maarif evrakındaki çoğul ifadelerden hareketle Vezirhan'daki ilk matbaası için 5 Mart 1873'de ruhsat talebinde bulunan kitapçı Hacı Hüseyin Ağa da şirket akdi yapılanlardan birisi olmalıdır. ${ }^{26}$

23 İstanbul'da yaşayan Acemler için Validehan'ın önemi ve merkezi konumu hakkında bkz. Filiz Dığıroğlu, “İstanbul-Tebriz Ticaret Hattında Validehan (XIX-XX. Yüzyıl)”, Türk Kültürü Incelemeleri Dergisi, 31 (2014), s. 69-112; Les Iraniens d'Istanbul, eds. Thierry Zarcone, F. Zarinebaf-Shahr (Paris-Tahran-Istanbul: Institut Français de Recherche en Iran, 1993).

24 BOA, MF MKT 8/55, 6 Kanun-i sani 1288/ 18 Ocak 1873.

25 BOA, DH MDK 220/88, 28 Z 1309/24 Temmuz 1892. Rûznâme-i Cerîde-i Havâdis'te 24 Nisan 1861'de çıkan bir kitabın satış yerleri ile ilgili ilandaki "Sahaflar Çarşusu’nda Ahmed Efendi'nin dükkânında ve Bayezid'de Acem kitapçılarında” ifadesi İranlı kitapçıların bir kısmının XIX. asrın ortalarında Beyazıt bölgesine yerleştiğini göstermektedir. İstanbul'da varlıkları iyice hissedilen Acem kitapçıların varlığına işaret eden bu ilanın yayınlandığı tarihe yakın bir zamanda Kitapçı Tahir'in de matbaa ruhsatı alması sadece bir tesadüften ibaret olmamalıdır. Rûznâme-i Cerîde-i Havâdis, 13 Şevval 1277/ 24 Nisan 1861, no. 123, s. 4'den aktaran İsmail E. Erünsal, Osmanlılarda Sahaflık ve Sahaflar, (İstanbul: Timaş, 2014), s. 91.

26 BOA, MF MKT 9/57, 5 Muharrem 1290/ 5 Mart 1873. 
Şimdiye kadar elde edilen bilgiler ışığında İranlıların M. Tahir Tebrizî önderliğinde kurdukları Şirket-i Sahafiye-i İraniye'nin Osmanlı matbuat hayatında şirketleşme faaliyetlerine öncülük ettiği görülmektedir. Ahter'in yayın hayatına başladığı 1876’ya kadar Tahir Tebrizî yayın faaliyetlerini Validehan'daki şirket matbaasında yürütmüştür. Matbaa-i İraniye’nin 1291 baskısı Gülistan'ın üzerindeki 'Tahir Tebrizî yardımıyla' kaydı da şirketle Tahir'in organik bağının ifadesi olarak yorumlanabilir. ${ }^{27}$ Her ne kadar Ahter faaliyetlerine başlayınca Tahir Efendi, şirketi Hacı Abbas Kerimov'a devretmişse de şirket işlerinden el çekmediği görülmektedir. 1892'deki kitap kovuşturmasında müfettişin kanunsuz kitap basmakla suçladığı Tahir Efendi için "Validehan'daki diğer matbaasında” ifadesini kullanması şirketle irtibatının devam ettiğini açıkça göstermektedir. ${ }^{28}$

Osman Nuri Ergin'in "Şirket-i Sahafiye-i Osmaniye ve Şirket-i Sahafiye-i İraniye’yi kurmak için çok fazla kişiye ihtiyaç yoktur, üç beş kişi bir araya gelip bu şirketleri kurmuşlarsa da Şirket-i Sahafiye-i İraniye, İranlı Hacı Hüseyin ve Hacı Abbas'ın üzerine kalmıştır” ifadeleri şirketle alakalı isimlere dair bilgileri arttırmaktadır. ${ }^{29}$ Hacı Hüseyin Efendi, Şirket-i Sahafiye-i İraniye'nin kurulduğundan beri işin içindeki Acem kitapçılardan biridir. ${ }^{30}$ Şirket-i İraniye'nin Tahirle birlikte anılan yegane ismi olan Abbas Kerimov ise birçok evrakta 'Şirket-i İraniyenin müdürü” olarak tanımlanmaktadır. ${ }^{31}$ Şirket-i Sahafiye-i İraniye müdürü olarak Bab-ı Fetva'dan 1890’lı yılların başında izin talebinde bulunan aslen İranlı olup Rusya vatandaşlı̆̆ında bulunan Abbas Kerimov'un, ${ }^{32}$ şirketin feshi ile ilgili 25 Haziran 1895 tarihli ilanda "tahvildar" sıfatıyla anıldığı görülmektedir. ${ }^{33}$ Şirket ile ilgili arşiv belgelerinde görülebildiği kadarı ile Abbas Kerimov, şirket var olduğu müddetçe müdürlük yapmıştır. ${ }^{34}$

27 Farsça Matbu Eserler Kataloğu (Osmanlıdan Günümüze), haz. Mustafa Çiçekler, (basım tarihi ve yılı yok), s. 58 .

28 BOA, DH. MDK 220/88, 28 Zilhicce 1309/24 Temmuz 1892.

29 Osman Nuri Ergin, Türkiye Maarif Tarihi, (İstanbul: Eser Neşriyat, 1977), III, s. 856.

30 Acem kitapçı Hacı Hüseyin Ağa hakkında yazılmış bir monogrofi için bkz. Dığıroğlu, Dersaadet'te Bir Acem Kitapçı.

31 Müdür olarak anıldığı belgelerden birkaçı için bkz. BOA, MF MKT 509/22; DH MDK $247 / 52$.

32 Meşihat Arşivi, Tedkîk-i Mesâhif ve Müellefât-1 Şer iyye Dairesi Defterleri, 1784, s. 60, 79.

33 BOA, ŞD 2970/31, 27 Muharrem 1313/20 Temmuz 1895.

34 BOA, DH. MDK 247/52, 5 Cemaziyelahir 1320/9 Eylül 1902. 
Şirketin hissedarları hakkında bilgilerimiz sınırlı olmakla birlikte Validehan'daki 'kaliçe ve sair eşyalar' taciri olarak anılan Hacı İbrahim Halil Efendi'nin en büyük hissedar olduğu ve Acem kitapçı Hacı Hüseyin Efendi'nin de bu şirkette yer aldığı ortaya konulmuştur. Henüz isimleri şirketle yan yana gelmemiş olsa da İstanbul'da yaşayan Acem topluluğu düşünüldüğünde başka kitapçıların ve özellikle Validehan'daki diğer tacirlerin de oluşumda yer aldığı düşünülebilir. Ancak Osman Nuri Ergin'in zikredilen ifadeleri doğru kabul edilirse daha fazla isim aramak şu aşamada anlamını yitirebilir. Herhalde eldeki sınırlı bilgiler çerçevesinde bir ticari işletme olarak Şirket-i İraniye'nin ortaklığında Kitapçı Tahir ve Hacı Hüseyin Efendi'nin tecrübelerini, Abbas Kerimov'un emek ve sermayesini, Validehan tüccarı Hacı İbrahim Halil Efendi'nin de sermayenin büyük bir kısmını koyduğunu söylemek yanlış olmayacaktır. Sermayenin geri kalan kısmında ismi geçenlerin bir dahli olup olmadığı henüz tespit edilememiştir. Sermayenin büyük kısmını ortaya koyan Hacı İbrahim Halil Efendi'nin oğlu İsmail'in de Şirket-i İraniye'de uzun süre çalıştığ görülmektedir. ${ }^{35} 15$ yaşından beri babasının ortağ 1 olduğu Şirket-i İraniye'de kitapçılık faaliyetlerine dahil olup, şirketin matbaasını Abbas Kerimov idare ederken kitapçı dükkanını İsmail Efendi yürütmüştür. İstanbul'daki Acem kitapçıların ailece kitapçılık yapması ve oğulların babalarının işlerine yardım etmesi ve sonrasında mesleği sürdürmesine dair benzer başka örnekler de vardır. ${ }^{36}$

İsmail Efendi'nin II. Meşrutiyet yıllarındaki bir belgede Şirket-i İraniye'nin müdürü olarak zikredilmesi, şirketin aktif işletmecisi olduğunu göstermektedir. ${ }^{37}$

35 Şirket-i Sahafiye hissedarlarından İsmail Efendi'nin 40 yaşlarında yaptığı müstakil bir matbaa açma talebindeki kendi beyanından 25 senedir İstanbul'da kitapçılık yaptığı dolayısıyla mesleğe 15 yaşında başladığı anlaşılmaktadır. BOA, DH. MKT 927/55, 23 Zilkaade 1322/29 Ocak 1905.

$36 \mathrm{Bu}$ örnekler içerisindeki en organize ve profesyonel tavra Ahter Matbaası'nda rastlanılmaktadır. M. Tahir’in oğlu Ali, Hakkaklardaki Ahter kütüphanesinde çalışırken diğer oğlu Kemal hem kitapçıda hem de Validehan'daki Ahter Matbaası'nda çalışmıştır. Tahir' in diğer iki oğlu Ahter gazetesine yazı desteği verdiği gibi damadı da bu işlere yardım etmiştir. Tahir ve ailesinin yayıncılık faaliyetlerine katkısı hakkında bkz. Yıldız, "İstanbul'da Bir Acem Matbaası”, s. 182-184. Yine benzer aile ilişkileri ile yürüyen diğer bir Acem matbaası olarak Naci Kasım ve faaliyetlerine dair ayrıntılı bilgi için bkz. Naşid Baylav, İlk Türk Kitap̧̧ılarından Hacı Kasım Efendi (1862-1962), (İstanbul: Ten Tıp ve Eczacılık Neşriyatı, 1962).

37 “...Adana'da Kitapçı Hacı Ali Vehbi adına Dersaadet'te Şirket-i İraniye müdürü İsmail Efendi tarafından gönderilen ve Maarif idaresince müsadere edilen kitapların durumu...” 
1895 'te şirketin feshi ile ilgili kendisinden habersiz verilen ilan ve hisse satışına yaptığı itirazın kabul gördüğü anlaşılmaktadır. Babasından kalan 23/40 hissenin usulsüzce Mirza Şefi'ye satışını durdurmuş gibi görünüyor. Bu fesh ve satış işleminin şirketin diğer ortakları ya da çalışanları ile ilişkisine nasıl yansıdığına dair elimizde net veriler olmasa da şirkette Abbas ve Tahir'den daha etkin bir pozisyona geçmesini sağladığı muhakkaktır. En azından bu olaydan sonra sadece kitapçı dükkânını işleten bir İsmail Efendi değildir. Nitekim II. Meşrutiyet yıllarında bazı resmi evraklarda 'Şirket-i İraniye Müdürü İsmail Efendi' olarak anılması, şirketin müdürlüğünü de yürüttüğünü gösterir.

II. Meşrutiyet öncesinde müstakil matbaa kurmak için girişimlerde bulunan İsmail Efendi, başvuruda kendini Şirket-i İraniye'nin hissedarı olarak tavsif etmiştir. Şirket-i Sahafiye-i İraniye hissedarlarından olduğu için Taşhan'da kuracağı yeni matbaada Şirket-i İraniye ile "kat-1 münasebet" etmesi ve matbaayı münferid işleteceğine dair teminat senedi istenmiştir. ${ }^{38}$ İsmail Efendi iki yıl önce de Çarşıkapı hanlarından birindeki mekânı matbaa olarak kullanmak istemiştir. O zaman da Şirket-i Sahafiye hissedarlarından İsmail Efendi'nin matbaa işine İranlıları karıştırmaması, söz konusu şirketle alakasını keseceğine ve matbaayı tek başına idare edeceğine dair teminat senedi vermesi istenmiştir. ${ }^{39}$ Söz konusu teminat senedini veren İsmail'in müstakil matbaa başvurularının nasıl sonuçlandığını bilemesek de artık 'Şirket-i İraniye' ile yollarını ayırmanın zamanı geldiğini düşünüp harekete geçtiği anlaşılıyor.

Görüldüğü üzere şirketin mukavelenamesi, sermayesi gibi mevzulara dair verilerimiz olmasa da kurucuları, hissedarları, müdürleri hakkında net olmamakla birlikte bilgi bulunmaktadır. Ancak Osmanlı matbuatındaki birçok işletmede olduğu gibi Şirket-i İraniye'de de matbaanın teknik özelliklerine, istihdam ve işçi

BOA, MF. MKT 1083/31, 28 Şevval 1326/ 23 Kasım 1908.

38 BOA, DH. MDK 278/98, 11 Cemaziyelahir 1325/ 22 Temmuz 1907.

39 İsmail Efendi Taşhan'dan önce Beyazıt'daki hanlardan birinde müstakil matbaasını açmak istemiş ancak kira bedelinde anlaşamayınca kendisine yeni yer olarak Taşhan’ı bulmuş ve işlemleri Taşhan'daki büyük mağaza için tekrar başlatmıştır. 1907 yılının ilk günlerinde İsmail Efendi İran şirketinden ayrılacağına dair teminat vermişti. Bu teminata Şirket-i İraniye hissedarlarından olarak şirketin 1. Ticaret mahkemesinde sürmekte olan davalarını takipten sarf-1 nazar edemeyeceği açıklamasını şerh düştüğü görülür. Bu konuya dair ayrıntılar için bkz. BOA, DH. MKT 927/55, DH. MKT 1120/55, Zabtiye Nezareti (ZB) 20/25, 16 E 1322; ZB 319/23, ZB 320/88. 
ücretlerine dair verilerden yoksunuz. ${ }^{40}$ Şirket matbaasında baskı işinde kaç eleman çalıştığı bile bilinmemektedir. Yegâne bilgimiz Ebuzziya Tevfik'in bir jurnalindeki oldukça ucuz fiyata neredeyse 'boğaz tokluğuna' İranlı/Acem işçilerin çalıştırıldıklarıdır. ${ }^{41}$ Acemlerden müteşekkil bir şirketin Acem/İranlı işçi çalıştırması son derece makul görünse de bu bir jurnal bilgisi olduğu için son derece ihtiyatla yaklaşılması gerektiği hatırdan çıkarılmamalıdır. Özellikle jurnaldeki 'boğaz tokluğu' ifadesi -henüz başka bir kaynakta benzeri bir bilgi ya da imaya rastlanılmaması sebebiyle- bu ihtiyatlı yaklaşımı zaruri kılmaktadır. Üstelik "Boğaz tokluğu” ifadesi doğru olsa bile diğer matbaalarda çalışan işçilerin ne kadar ücret aldığına dair kesin verilerden yoksun olmamız, kıyas yapmamızı engellemektedir. Ayrıca hurda kâğıt satışı dolayısıyla belgelere yansıyan bir şirket çalışanının isminde de hiçbir Acemlik alameti sezilmemektedir. İranlı Abbas Ağa’nın destgahtarı Osman Paşazade Emin Bey'in ${ }^{42}$ isminin Acem kökenli olduğuna dair hiçbir emare taşımaması, yukarıdaki jurnal bilgisini bir kez daha ihtiyatlı kullanmak gerektiğini göstermektedir. Ayrıca destgahtar Emin Bey'in varlığı çoğunluğu Acem olmakla birlikte Acem olmayanların da şirkette kendilerine bir yer bulabildiğine delalet etmektedir.

\section{Şirket-i Sahafiye-i İraniye'nin Faaliyet Alanları}

Şirketin Validehan'daki basımevi ve Beyazıt'taki dükkân ile tab'[matbaacılık] ve neşr[yayıncı/kitapçlık]olmak üzere iki ana faaliyet alanı vardır. Şirket-i Sahafiye-i İraniye matbaasının aynı isimle anılan kitapçısı Beyazıt'taki Askeri matbaanın altında yer almaktaydı. Şirket'in 1886 Kasım'ında baskı ruhsatı aldığ Şifa-i Şerif ìn son sayfasındaki ibareler şirketin bir kitapçısı olduğunu açıkça

40 Her ne kadar Şirket-i İraniye ismi evrakta zikredilmese de İranlı Abbas Ağa’nın destgahtarı olarak Osman Paşazade Emin Bey'den bahsedilmektedir. Arşiv evrakında açılayııı herhangi bir bilgi olmamasından dolayı buradaki "destgahtar" ifadesinin matbaadaki teknik eleman ya da dükkandaki satış elemanı için de kullanılmış olabileceği hatırdan çıkarılmamalıdır. Bkz. BOA, MF MKT 79/18, 3 Kanun-i sani 1298/15 Ocak 1883.

41 "Çünkü bu matbaa taş basmasından ibaret olduğundan ve bir takım ekmek parasına muhtaç seele-i İraniye'yi hidmeti tıbaáatde boğazı tokluğuna istihdam eylediğinden çıkardığı kitapları nihayet derecede ehven satar." Bkz. Asaf Tugay, İbret: Abdülhamid'e Verilen Jurnaller ve Jurnalciler, (İstanbul: Okat Yayınevi, 1962), s. 129.

42 BOA, MF. MKT 79/18, 3 Kanun-i sani 1298/15 Ocak 1883. 
göstermektedir. ${ }^{43}$ Hem kendi bastıklarını hem de piyasanın ihtiyacı olan ülke içinde ve dışında basılmış kitapları sattıkları dükkânları Beyazıt'tadır. Beyazıt'taki dükkânda Hind ve İran coğrafyasında basılmış kitapların bulunduğu ifade edilir. Elbette öncelikle şirketin bastığı kitapların kendi dükkânlarında şatışa çıkarıldığı açıktır. Bastıkları kitabın arkasındaki faaliyetlerini tanıtıcı bölümde kitap getirttikleri bölge olarak Hind ve İran coğrafyasını özellikle zikretmişlerdir. Acem kitapçıların bu coğrafya ile irtibatlarının olması ve oradaki matbuatın İstanbul'daki tedarikçisi olarak kendilerini lanse etmeleri anlaşılabilir bir şeydir. Çünkü doğdukları, eğitim gördükleri, dilini ve kültürünü bildikleri İran coğrafyasında artlarında bıraktıkları akrabaları, arkadaşları, hocaları veya başka iletişim kanalları üzerinden rahatlıkla irtibata geçebilirlerdi. Belki de mevcut ilişki ağlarını kitap ticareti ve kitap trafiği üzerinden değerlendiriyorlardı. İstanbul'un etki sahası oldukça geniş olan Acem kitapçısı Ahter'in Hakkaklar Çarşısı'ndaki dükkânının üzerinde bulunan 'İran ve Hindistan Matbuatı' levhası da bu zaviyeden okunmalıdır. ${ }^{44} \mathrm{Bu}$ durum Acemlerin söz konusu bölgeden İstanbul'a doğru bir kitap akışını yönettiğine işaret ettiği gibi İstanbul'da bu kitapların bir alıcı kitlesi olduğuna da işaret etmektedir.

Şirket sahipleri Beyazıt'taki dükkanlarında İran ve Hint matbuatından temin ettikleri Arapça ve Farsça kitaplarla İstanbul'un "dil-teşnegân-1 ilm u marifet" okuyucularını buluşturmayı hedeflemişlerdi. ${ }^{45}$ Belki Şirket-i İraniye’nin bağlantılı veya etkili olduğu coğrafyaya Mısır’’ da dahil etmek gerekir. Şirket-i İraniye adına İskenderiye'den gelen bir sandıktaki 4 ciltlik Arapça kitaba incelenmek üzere el konulması, Mısır ile şirketin bir ilişkisi olduğuna delalettir. ${ }^{46}$ Her ne kadar el konulan kitapların izlerini sürmek ve incelemenin sonucunu görmek mümkün olamasa da İskenderiye’den gelen kitapların, kitapçı dükkânında satılmak üzere

43 “... Maarif nezaret-i celilesi canib-i alisinden fi 17 S 1304 tarihli ve 860 numaralı ita buyrulan ruhsatname-i alileri mucebince tahrir ve tashihince gayet itina ve emr-i tashihini dahi Irak ve Arap ulemasından bir zat-1 fazıl ve muktedire tevdi ve ba'de't-tashih Validehanı'nda kain Şirket-i İraniye Matbaası'nda tab olunub Sultan Beyazıd civarında misafirhane-i askerî tahtında üç numaralı şirket-i mezkur kütüphanesinde füruht olunduğu gibi..." Kadı İyaz b. Musa, eş-Şifa Bi-Ta'rifi Hukuki'l-Mustafa, İstanbul t.y.. (vurgular yazara ait). Celaleddin Mirza’nın Nâme-i Hüsrevan isimli eserinin satın alındığına dair kayıtlardaki kitapçı dükkanı burası olmalıdır. Bkz. Rahim Reis Niya, İan ve Osmanî der Asitane-i Karn-ı Bistom, I, (Tahran: Neşr-i Mebna; Tebriz: İntişarat-ı Setude,1328), s. 857.

44 BOA, MF. MKT 657/52, 16 Safer 1320/25 Mayıs 1902.

45 Bkz. EK 1.

46 BOA, MF TTD 22/74, 1 Zilkaade 1309/28 Mayıs 1892. 
sipariş edilme ihtimali ile Mısır'daki yayıncıların İstanbul'daki temin mekanı olarak şirketi tercih etme ihtimalini akla getirmektedir. Elbette İranlı muhaliflerin İran dışında etkin olup, yayın faaliyetlerinde bulundukları merkezlerden biri olan Mısır ile ilişkileri bu bağlamda da değerlendirilebilir.

Yoğun yayıncılık faaliyetinde bulunan Şirket-i İraniye'nin 20. yüzyılın başlarında Havuzlu Han'da bir de deposu bulunduğu anlaşılmaktadır. ${ }^{47}$ Söz konusu depoda Validehan'da şirket namına bastığı kitapları ile Hint ve İran coğrafyasından İstanbul piyasasında satmak üzere getirttikleri kitapları muhafaza ediyor olmalılar. Şirketin ticari bağlarının nerelere uzandığı ve kitap dağıtım şebekesini nasıl işlettiğine dair elimizde sınırlı bilgi olsa da Anadolu’ya çokca kitap gönderdiğini tahmin etmek güç değildir. ${ }^{48}$ Şirket-i Sahafiye müdürü sıfatıyla İsmail Efendi'nin Adana’daki kitapçı Ali Vehbi adına gönderdiği kitaplara el konulması bu tür ilişki ağlarından birisini çözmemizi sağlar. ${ }^{49}$ El konulan kitapların ders kitabı olma ihtimali oldukça yüksektir.

Maalesef şirketin İstanbul merkezli dağıtım ağına ve tedarik mekanizmasına dair elimizde ayrıntılı bilgi bulunmamaktadır. Kitapçı Tahir Tebrizî ve Hacı Hüseyin Ağa’nın tecrübeleri ve bağlantılarının bu hususlarda şirketi bir adım ileri taşıdığını tahmin etmek güç değildir. ${ }^{50}$ Sınırlı bilgilerimizden birisi Şirket-i İraniye müdürü olarak Abbas Ağa’nın bastığı kitaplardan Sebatü’l-acizin’in arkasına koyduğu ilandır. Bu ilanda Taşkent ve Buhara’da şubesi olduğundan ve o bölgeden kitap bastırmak isteyenlerin taleplerini İstanbul'da titizlikle karşılayabileceğinden

47 BOA, DH. MDK 247/52, 5 Cemaziyelahir 1320/ 9 Eylül 1902.

48 Kendi müstakil matbaası olmasına rağmen Şirket-i Sahafiye-i İraniye’ye de destek olan İstanbul'un etkili Acem kitapçılarından Hacı Hüseyin Ağa’nın başta Anadolu olmak üzere imparatorluğun Arap vilayetlerine hatta Cezayir ve Tunus'a kadar Mushaf ve kitap gönderdiğine dair anlatılar için bkz. Dığıroğlu, Dersaadet'te Acem Kitapçı. Her ne kadar Şirket-i İraniye matbaası olmasa da kendi matbaası üzerinden benzer şekilde sevkiyat yapan Acem kitapçı Hacı Hüseyin'e dair bir evrak, şirketin de benzer ilişki ağlarını kurarak kitap tedavüle soktuğuna hamledilebilir. “Teb'a-i İraniyye’den Kitapçı Hacı Hüseyin Efendi’nin matbaa dükkânında hizmetkâr İsak tarafından Anadolu’ya sevk olunmak üzere götürülen dört balya kaba kağıt miyânında zuhûr eden üç yüz seksen beş aded mühürsüz Mushafşerîfile dört yüz seksen dört aded kitap ve iki bin adedi mütecâviz nüshanın gönderildiği...” Ayrıntılı bilgi için bkz. BOA, MF. TTD 53/68, 29 L 1319/ 8 Şubat 1902.

49 BOA, MF MKT 1083/31, 28 Şevval 1326/ 23 Kasım 1908.

50 Kitapçı Tahir ve bağlantıları için bkz. Yıldız, "İstanbul'da Bir Acem Matbaası"; Hacı Hüseyin ve bağlantıları için bkz. Dı̆̆ıroğlu, Dersaadet’te Bir Acem Kitapçı. 
bahsetmektedir. ${ }^{51}$ Aynı eserin bir sonraki baskısında söz konusu ilanın muhtasar hali kullanılmıştır. ${ }^{52}$ Maveraünnehir bölgesindeki İstanbul baskısı kitapların varlığı şirket ilanlarının işe yaradığına ve Şirket-i İraniye’nin matbaacılık hizmetinin uzandığ 1 coğrafi alana işaret etmektedir. Nitekim ilanda Taşkent ve Buhara'da şirketin şubesi olduğunun vurgulanması kitap trafiğinin ne kadar yoğun olduğuna dair önemli bir gösterge olarak da okunmalıdır. İlanın yer aldığı eserin bir dini kitap olması, Orta Asya müslümanlarının hilafet merkezi İstanbul'u her anlamda merkez kabul ettiklerini ve burada kitap bastırma isteğini göstermektedir. ${ }^{53} \mathrm{Bu}$ taleplere Şirket-i İraniye'nin karşılık vermesi de Osmanlı sınırları dışına hizmet veren bir ticari politika benimsediklerini göstermektedir.

\section{Şirket-i Sahafiye-i İraniye'nin Yayın Faaliyetleri}

Şirketin ne tür kitaplar bastığı, yayın katalogları ve kütüphane kayıtları üzerinden ne tür kitapları basmak istediği de devlet mercilerindeki izin alma süreci takip edilerek tespit edilmiştir. Osmanlı kitap denetim mekanizması çerçevesinde yayıncıların basmak istedikleri her kitaba devlet makamları tarafindan her zaman onay verilmesi söz konusu değildir. Tüm yayıncılar gibi İranlı matbaacılar da bu kurallar çerçevesinde faaliyetlerini sürdürmüş hatta bazen illegal yollara başvurdukları da olmuştur. Elbette bu illegal yani kaçak/korsan baskı kitaplar Osmanlı mercilerince yakalandığı nispette tespit edilebilmiştir. Çünkü sadece devlet tarafından ele geçirilebilenlerin kayıtları arşivde muhafaza edilmişsir. $\mathrm{Bu}$ bağlamda söz konusu kayıtların dışında ele geçirilemeyen kaçak ve korsan baskıların da olduğu dikkate alındığında Şirket-i Sahafiye-i İraniye’nin Osmanlı

51 Sebatül-Acizin, (İstanbul: Matbaa-i Şirket-i İraniye, 1310), s. 129.

52 Sebatül-Acizin, (İstanbul: Matbaa-i Şirket-i İraniye, 1311), s. 138. (Bu ilandan beni haberdar eden değerli meslektaşım Ali Emre Özyıldırım’a teşekkür ederim.)

53 19. yüzyıl ortalarından itibaren hilafet merkezi İstanbul'un hem İslam alemi hem de Türk dünyası için önemli yayıncılık merkezlerinden biri haline gelmesi Özbek kitap taciri Sıddık Hoca Hocendi üzerinden takip edilebilir. İstanbul-Orta Asya hattındaki Orta Asyalı Türk okurlara yönelik gerçekleştirilen matbu kitap ticaretinin önemli figürlerinden biri olan Özbek kitap taciri Sıddık Hoca Hocendi ve faaliyetlerine dair kaleme alınmış vasıflı bir çalışma için bkz. Ali Emre Özyıldırım, "İstanbul'da Basılıp Orta Asya’da Satılan Kitaplar ve Şeyh Süleyman Efendi ile Tâcir-i Kütüb Sıddık Hoca Hocendînnin Faaliyetleri”, Müteferrika, 54 (2018), s. 75-116. Şirket-i İraniye müdürü Abbas Ağa’nın bastığı kitapların arkasına koyduğu ilanları benzer şekilde yorumlayan bölüm için özellikle bkz. s. 88-89. 
matbuat tarihinin en hareketli ve renkli kitap şirketlerinden biri olduğuna hiç şüphe yoktur. ${ }^{54}$

Dersaadet'teki İranlı kitapçılar İstanbul'daki diğer meslektaşları gibi Mushaf-ı şeriften, ders kitabı, Jön Türk neşriyatı, takvim, roman, dini kitap, destan türü halk kitapları, tiyatro ve kantolara kadar uzanan çok geniş bir neşriyat yelpazesine sahiptirler. Bu bağlamda İranlıların hakim olduğu bir kitap şirketinin neler bastığını tahmin etmek çok da zor değildir. Şirket-i Sahafiye-i İraniye bilhassa Envârül-Aşıkîn, Muhammediye, Ahmediye, Siyer-i Nebi, Battal Gazi, Billur-ı Azam, Hayber Kalesi, Kan Kalesi, Ebu Ali Sina, Aşık Kerem, Aşık Garip gibi Türkçe kitaplar basmıştır. ${ }^{55}$

Literatürde bu kitaplarla anılan şirket yayınlarının maalesef dönemindeki bazı yayınevleri gibi fihristleri yayınlanmamıştır. Matbaacıların neler bastığı ya da kütüphanelerin [kitapçıların] sattığı kitaplara dair yayınladıkları fihrist/katalogdan şirketin mahrum kalması basım ve yayın faaliyetlerine dair bilgilerimizi sınırlandırmaktadır. ${ }^{56} \mathrm{Bu}$ sınırlılığı aşmanın yollarından biri Türkiye’deki mevcut kütüphane kataloglarını taramaktır. Kütüphane katalogları arasındaki uyuşmazlıklar ve birçok başka sebep, kütüphane katalog taramalarının Şirket-i Sahafiye-i İraniyye matbaasında basılanların tam bir listesini oluşturmaya elverişli bir yöntem olmadığını göstermiştir. Şirketin ne tür kitaplar bastığını ve

54 Şirket-i Sahafiye-i İraniye'nin de dahil olduğu İstanbul'daki Acem kitapçı ve sahaf esnafının kaçak ve korsan baskı yaptıklarına dair arşivde bol miktarda müfettiş raporu ve evrak bulunmaktadır. Müstakil bir çalışmayı hak eden bu konuya dair onlarca evraktan birkaçı için bkz. BOA, MF. MKT 25/148, 147/69, 392/13, 509/22, DH. MDK 220/171.

55 Ergin, Türkiye Maarif Tarihi, s. 856.

56 Fihrist yayınlayan kitapçılara değinmek gerekirse İstanbul kitapçıları arasında Atina Üniversitesi'nden mezun olan ve ilk kitapçı dükkanlarını 1858'de Galata'da kuran Andonios ve Nikolaos Deposta Kardeşler 1869'da bu tarihten itibaren düzenli olarak çıkaracakları ilk kataloglarını yayınladılar. Türkçe kitaplara dair ilk katalog yayımlayan ise Türkler arasında 'Kitapçı Arakel' olarak bilinen Ermeni Arakel Tozluyan'dı. İlk kataloğu (1301/1884) çok başarılı oldu ve özellikle Batılı Şarkiyatçı ve bilginler tarafından takdirle karşılandı. Bkz. Johann Strauss, "Osmanlı İmparatorluğu’nda Kimler, Neleri Okurdu? (19.-20.Yüzyıllar)”, Tanzimat ve Edebiyat Osmanlı Istanbulu’nda Modern Edebi Kültür, haz. Mehmet Fatih Uslu-Fatih Altuğ, (İstanbul: Türkiye İş Bankası Kültür Yayınları, 2014), s. 22; Acem kitapçılar içinde fihrist yayınlayan Şirket-i Hayriye-i Sahafiye’nin sahibi Hacı Hüseyin Ağa'dır. 'Şirket-i Hayriye-i Sahafiye müdürü El-Hac Hüseyin Efendi'nin kütüphanesinde bulunan kütüb-i mütenevvianın fihristi' adıyla 1311'de yayınlanan bu katalog için bkz. Dığıroğlu, Dersaadet'te Bir Acem Kitapçı, s. 36-43. 
sattığını arşiv belgeleri üzerinden takip etmek de tek başına sonuca ulaşmak için yeterli değildir. Çünkü bu belgeler ya bir eser basımı için ruhsat talebi ve buna verilen cevaplar ya da matbaa ve kitapçı dükkanı teftiş raporlarıdır. Bu raporlarda adı geçen kitaplar çoğunlukla mahzurlu görülen "muzır neşriyat" veya "asar-1 memnua” ya da ruhsatsız basılmış korsan nüshalardır. Bu hususlar göz önünde bulundurularak basılmış kitaplar öncelikli olmak üzere karşılaşılan eserlerin değerlendirilmesi suretiyle şirketin neşriyat politikasına dair bazı çıkarımlar yapılmıştır.

Şirket-i İraniye tarafından 1871'de basılmış Ahmed el-Ahsâînin el-Fevâid adlı kitabı bulduğumuz en erken tarihli şirket baskısıdır. ${ }^{57}$ Bu baskı, Şirket-i İraniye'nin kuruluş tarihi ile mütenasip olarak neşriyata başladığını gösterir. $\mathrm{Bu}$ bilgi doğru kabul edilirse İranlı/Acem kitap şirketinin İstanbul'daki ilk neşriyatının şii kelamcı Ahsâ̂̀ye ait olması tesadüfi olarak mı yorumlanmalıdır? Şia’ya ait bir eserin tercihi sembolik anlamların ötesine işaret ediyor olmalıdır. Peşisıra İstanbul'daki İran sefareti başkatip ve tercümanı olan Muhammed Rıza Efşar'ın hazırladığı Elifbầ yı yayınlamıştır. Daha sonraları bu gramer kitabının Debistan-ı İraniyân Matbaası'nda da basılması, şirketin İstanbul'daki Acem topluluğun çocuklarına Farsça eğitim materyali hazırlama işine giriştiğini göstermektedir. ${ }^{58}$

Bu iki yayından ancak birkaç yıl sonra Şirket-i İraniye'nin yeni baskıları, kitap piyasasında görülebilmiştir. Yeni baskılar içindeki iki Farsça eser, şirketin İstanbul'daki Farsça neşriyatı sürdürdügünü göstermektedir. Bunlar 1291'de Farsça basılan Feridüddin Attar'ın Pendname-i Attar ${ }^{59}$ ile Sadi'nin Gülistanı ${ }^{60}$ dır. Bu

57 Katalogdaki baskı tarihi h.1287 olup 1870-71 yıllarına tekabül etmektedir. Tarihte ay ve gün belirtilmediği için miladi takvimdeki karşılığı tam tespit edilememekle birlikte metinde ilk baskı tarihi olarak 1871 yılı zikredilmiştir. Katalog için bkz. İstanbul Belediye Kütüphanesi Alfabetik Kataloğu, I, Osman Nuri Ergin Kitaplarn Arapça ve Farsça Basma Eserler, haz. M. Orhan Durusoy, (İstanbul: İstanbul Belediye Kütüphanesi, 1953), s. 170.

58 Farsça Matbu Eserler Kataloğu, s. 134-135.

59 Kütüphanelerdeki Farsça kitap kataloglarında Pendnamènin aynı yıla ait farklı ebatlarda nüshaları görünmektedir. Ebatları farklı görünse de baskı yılı ve sayfa sayılarında bir farklılık görünmemesi, aynı baskı olduğuna işaret kabul edilmiştir. Feridüddin Attâr, Pendnâme-i Attâr, (İstanbul: Şirket-i İraniye M., 1291), 61 s., kaydı için bkz. İstanbul Belediye Kütüphanesi Alfabetik Kataloğu I, s. 256; Feridüddin Attâr, Pendnâme-i Attar, (İstanbul: Matbaa-i Şirket-i İraniye, Receb sonu 1291/1874), 61 s., kaydı için bkz. Farsça Matbu Eserler Kataloğu, s. 116.

60 Sadi Şirazî, Gülistân, (İstanbul: Matbaa-i İraniye, 1291/1874-5), taşbaskı, 228 s., 19.3x12.2 (15x8.6), İbn Muhammed Sâdık Muhammed Tâhir et-Tebrizînin yardımıyla kaydı için bkz. Farsça Matbu Eserler Kataloğu, s. 58. 
defa seçilen Farsça kitaplar Osmanlı okuru için daha alışıldık ve klasik türden ve genel okuyucuya hitab eden edebî, tasavvufî eserlerdir. Şirketin Osmanlı toplumunda bir kültür dili olarak varolan Farsça üzerinden neşriyatını devam ettirmesi Osmanlı okurunu hedefleyen bilinçli ticari tercihlerdir. ${ }^{61}$ Şirket adına yapılan ilk Türkçe baskılar da 1291 yılına aittir. Ahmediye ve Ayda İsmiyle Yad Olunan Operanın Tercümesi ${ }^{62}$ ile ilk Türkçe kitaplarını yayınlayan şirket, İstanbul matbuat hayatında iki dilde hizmet veren bir matbaa olarak devam etmek niyetini izhar etmiştir. Söz konusu matbaada 1294'te ikinci baskısını yapacak olan Farsça Gülistan’’n da taşbaskı tekniği ile basıldığını zikretmek gerekir.

Şirketin ikinci yılında halkın çok rağbet ettiği Envaru'l-Â̧̧ııı̂n kitabı basılmıştır. İkinci baskısının 12 yıl sonra gerçekleşmesi, 'popüler' bir kitap için oldukça geç bir baskı tekrarıdır. Envaru'l-Âşıkîn' in çok okunduğu ile ilgili bir şüphe olmaması ile Şirket-i İraniye'nin 'kaçak suretle' baskı yaptığına dair bulgular birlikte düşünüldügüñnde iki baskı arasında kaçak suretle de baskıların yapılmış olma ihtimali akla gelmektedir. Öte taraftan bu tür kitapların bireysel okumadan ziyade meclislerde toplu okundukları da hesaba katıldığında iki baskı arasındaki süre makulleştirilebilir. ${ }^{63}$ Osmanlı kıraat meclislerinde çokça okunan

61 Strauss'un 'okur cemaatleri' ve 'dilsel cemaatler' olarak kavramlaştırdığı şekilde İstanbul'daki ecnebi nüfusun bir parçası olan İranlıların Farsça basması her durumda anlamlıdır. Zira İstanbul'da Osmanlı Türkçesinin yanı sıra Farsça, Arapça, Yunanca, Ermenice ve İbranice lisanları 'okur cemaatleri'ne hitap edebilirdi. Farsça ve Arapça diğer dillere göre daha farklı bir konumdaydı. Bunlar Osmanlı toplumunda bir etnik dil olmaktan daha fazla anlam taşıyordu. Örneğin Farsça, Osmanlı Türkleri arasındaki eğitimli sınıf için bir kültür dilidir. Strauss, "Osmanlı İmparatorluğu’nda Kimler”, s. 7-8. Görüldüğü üzere Strauss'un kastettiği anlamdaki Farsça neşriyat, Şirket-i İraniye’nin yayın politikasına rahatlıkla dahil edilebilir.

62 Tercüme operanın yayıncısı kayıtlarda "Şirket-i Sahafiye” olarak görünmektedir. O yıllardaki yegane sahaf şirketinin Acemlerin kurduğu sahaf şirketi olduğu düşünüldüğünden, bu kayıt Şirket-i İraniye baskısı olarak değerlendirilmiştir.

63 Osmanlıdaki okuma meclislerine ve bu meclislerde neler okunduğuna dair ayrıntılı bilgi için bkz. Zehra Öztürk, "Osmanlı Döneminde Kıraat Meclislerinde Okunan Halk Kitapları”, TALID, V, 9 (2007), s. 401-445. Z. Öztürk'ün de dikkat çektiği gibi matbaanın yaygınlaşması ile XIX. ve XX. yüzyıllarda okuma alışkanlıkları değişse de Mevlid, Muhammediye, Ahmediye, Mizraklı İmihal, Hz. Ali Cenkleri, Battalgazi Hikâyeleri gibi kitapların toplantılarda okunup dinlenilmesi ilk devirlerindeki canlılığını bu dönemlerde de sürdürmüştür. Bu dönemde yazılmış kıraat meclislerinde okunmaya yönelik kitaplar da vardır: Mehmed Münib Ayıntabînnin Siyer-i Kebîr’i, Münif Fehim Paşa’nın Aziziye diye meşhur olan Muhtasar (Kudîrî) Tercümesi ve son dönemlerde yaygınlaşan Şürutu's-salât Tercümesi bunlar arasında en önemlileridir. Aynı makale, s. 406. 
Muhammediye’ nin şirketin ikinci yıl baskıları arasında yer alması, Osmanlı coğrafyası müslüman okurunu tanıyan bir yapı ile karşı karşıya olduğumuzu gösterir. Taşbaskı usulüyle resimli olarak basılan Muhammediyénin tirajını bilemesek de şirketin kârını arttıran bir tercih olduğunu iddia etmek abartılı olmaz. Çünkü Envarul-Aşııîn, Muhammediye gibi halka yönelik popüler kitap baskıları, ticari beklentisi yüksek bir kitap şirketi politikasının izleridir. Yine bilinçli bir şirket politikası olarak resimli baskı tekniğinin kullanılmasından bahsedilmelidir. Resimli baskı yöntemi, Osmanlı okurunu cezbetmek için kullanılan bir taktikti ${ }^{64}$ ve Şirket-i İraniye de bu yöntemi gayet başarılı bir şekilde uygulamaktaydı.

Şirketin erken baskıları içinde dikkat çeken bir eser ise James Redhouse'ın meşhur sözlüğünden yapılan seçkidir. Kayıtlarda ilk olarak İlaveli Muntehabat-ı Lugat-ı Osmaniye’nin sadece 2. cildi basılmış görünüyor. Bu baskıdan altı yıl sonra iki cildin birden basıldığı görülmektedir. Sonraki yıllarda basılan Kitab-ı Tercüman-ı Türkî ve Arabî ve Farisî, şirketin sözlük/lugat basımına önem verdiğini göstermektedir. Taşbaskı tekniği ile 2. baskısı da yapılan bu sözlük, şirketin İstanbul okur piyasasının ihtiyaçlarına uygun yayın yaptığına işaret etmektedir. Çünkü yayın hayatına Vankulu gibi bir sözlükle başlayan Müteferrika matbaasından itibaren Osmanlı matbuatında sözlük basımının her dönem revaçta baskılar olduğu gözlenmiştir. ${ }^{65}$ Yine bu bağlamda İstanbul'da 1820'lerden itibaren basılan Sünbülzade Vehbi'nin Farsça-Türkçe lugatının Şirket-i İraniye tarafından 1880'lerde basılması anlamlıdır. ${ }^{66}$

Şirket-i İraniye’nin Osmanlı kitap piyasasındaki 5 yıllık varlı̆̆ının ardından yayın politikasına ders kitaplarını eklediği görülmektedir. Erkan-1 Harbiye Mirlivası Yusuf Âgah Paşa'nın Mekteb-i Harbiye muallimliği esnasında basılan Menazır’ bu türden kitaplara örnek olmalıdır. ${ }^{67}$ Taşbaskı ve levhaların yer aldığı Menazır, 1297 yılında basılmışıtır. Aynı yıl 15 sayfalık hacmiyle [Muallim] Fevzi’nin hazırladığı

64 Osmanlı çocuk yayıncılığında resimli baskıların gelişimine dair ayrıntılı bilgi için bkz. Fortna, Geç Osmanl, s. 212-219, 241-248.

65 Müteferrika matbaasının son baskısının da Farsça bir sözlük olması Osmanlı matbuat tarihi açısından dikkat çekicidir.

66 En erken İstanbul baskıları olarak Tuhbe-i Vehbî 1256/1841, Şerh-i Tuhfe-i Vehbî 1237/1822 tarihli görünmektedir. Farş̧a Matbu Eserler Kataloğu, s. 169. İlginçtir ki bu katalogda Şirket-i İraniye baskıları zikredilmemiştir.

67 Ulum-1 riyaziyye mütehassıslarından Âgâh Paşa ile ilgili ayrıntılı bilgi için bkz. Bursalı Mehmed Tahir, Osmanlı Müellifleri, haz. M. Ali Yekta Saraç (Ankara: TÜBA Yayınları, 2016), III, s. 1231. 
Pak Nihâd ve Pak Dâmen adlı bir risale de Şirket-i İraniye matbaasında basılmıştır. 1299'da basılan Leyla [Saz] Hanım'ın Divan-ı Leyla Hanım'ı da şirketin aktüel edebiyat yayınlarından biri olarak dikkat çekmektedir. Şirketin yazar kadrosunda Leyla Hanım'ın yer alması Osmanlı matbuatında giderek varlığı hissedilecek olan kadın yazarlara yer ayırmayı hedefleyen bilinçli bir adım belki de sadece genel edebiyat okurunu hedefleyen bir tercihtir. Bu tercihin nedeni netleştirilemese de her iki amaca da hizmet edeceği akıldan çıkarılmamalıdır.

Meşhur ve Mütearef Hoca Nasreddin Letâifi ve Kenarinda Raz-i Nihan ile Mah-Firûze Sultan Hikâyeleri nin kataloglarda baskı tarihi görülmemektedir. ${ }^{68}$ $\mathrm{Bu}$ eserin halkın çokça rağbet ettiği ve okumak istediği Nasreddin Hoca hikayeleri olması, şirketin en başından beri çok okunan ve çok satılan kitaplara yönelik bir baskı politikası izlediğini göstermektedir. Yine baskı tarihi belli olmayan Arzu ile Kanber ve Asuman ile Zican adlı kitaplar da halk arasında rağbet edilen hikayelerin metinleri olmaları hasebiyle Şirket-i İraniye'nin isabetli ticari öngörüsü çerçevesinde basılmış eserler olarak zikredilmelidir.

Şirket-i İraniye'nin kataloglara pek de yansımayan ancak arşiv vesikalarında tespit edilebilen 'kaçak/korsan’ baskılar yaptığı görülmektedir. Ebuzziya Tevfik, bir jurnalinde Şirket-i İraniye'den şöyle bahsetmektedir: "Valide Hanı’nda Şirket-i İraniye namına bir matbaa olarak herhangi kitab-1 mukaddes muvafik gelirse nihayet derecede muzır olsun orada basılır. Mesela Ziya Paşa'nın Zaptiye nazırı Hasan Paşa lisanında yazdığı meşhur Zafername şerhi orada defaatle basılarak mülkün her tarafinda neşir olundu. Çünkü bu matbaa taş basmasından ibaret olduğundan ve bir takım ekmek parasına muhtaç seele-i İraniye’yi hidmeti tıba'atde boğazı tokluğuna istihdam eylediğinden çıkardığı kitapları nihayet derecede ehven satar. Halk ise kütüb-i nefise aramakta değil ucuz kitap almak arzusunda olduğundan binlerle kitap satar." ${ }^{69}$ Aynı jurnalde şirket, korsan kitap basarak müelliflerin ve matbaa sahiplerinin haklarını gasp etmekle suçlanmaktadır. Kitapçı Arakel'in Kıraat ${ }^{70}$ adıyla mektepler için bizzat telif ederek çocukların faydasına sunduğu kitabın revaçta

68 Bu kitaplar Özege, Eski Harflerle Basılmış Türkçe Eserler Kataloğu’nda 11929 ve 13300 numaralarında kayıtlıdır. Seyfettin Özege kataloğunda iki farklı şekilde kaydedilen kitapların farklı baskılar olup olmadığı tespit edilememiştir. Sayfa sayıları farklı görünen kitapların ortak özelliği, taşbaskı ve resimli olmalarının yanı sıra matbaa isimlerinin "Matbaa-i Mahsusa-i İraniye” olarak kaydedilmeleridir.

69 Tugay, İbret, s. 129.

70 Kitapçı Arakel'in Talim-i Kıraat adlı ders kitabı 1301(1895) tarihinde ilk defa Ebüzziya matbaasında olmak üzere değişik tarihlerde ve matbaalarda toplam otuz altı baskı yapmıştır. 
olduğunu gören Şirket-i İraniye o kitabı tab` ederek 30 paraya satmaya başlamıştır. Arakel Efendi'nin Maarif Nezareti'ne hukukunun muhafazası için yaptığı başvurular sonuçsuz kalmıştır. ${ }^{71}$ Yine bu şirket Namık Kemal'in Vatan yahut Silistre ismindeki tiyatrosu ile Zavallı Çocuk ismindeki tiyatroyu da neredeyse 50 defa tab' etmişken ne Maarif Nezareti ne de Zabtiye Nezareti korsan baskıların önüne geçememiştir. Hatta Kemal Beyin Rüyası namıyla bir risale daha tab' edilmiş ve elde kitap satan Acemlerden birinin Köprü üzerinde "Rüya-yı Kemal” diye bağırarak sattığını gören Ebuzziya Tevfik, iki nüshasını üzerinde 3 kuruş fiyat bulunmasına rağmen 40 para vererek nüshaları aldığını ifade etmiştir. ${ }^{72}$ Ebuzziyànın şirkete dair aktarımları oldukça ucuz fiyata korsan baskıları piyasaya sürdüğü yolundadır. Devlet makamları tarafından ele geçirilen kaçak şirket baskılarına dair arşivde çokça belgeye rastlanması, Ebuzziya’nın iddiasını kuvvetlendirmektedir. Yeni Camide Postahane-i Âmire yakınlarında sergi açan İranî Hasan'ın tezgâhına yapılan baskılarda ele geçen 32 kitabın matbaalarına dair bilgi verilmemiştir. Ancak el konulan kitaplar içindeki 3 adet $Z a$ vallı Çocuk $^{73}$ ve Ebuzziya’nın iddiaları birlikte düşünüldüğünde kuvvetle muhtemel Şirket-i İraniye baskısı olan kitabın yine İranlı seyyar kitapçılar tarafından piyasaya sürüldügüunü akla getirmektedir. Bunun yanı sıra İranlı Hacı Hüseyin Efendi’nin matbaasında basılan yasaklı kitaplardan Evrak-ı Perişan'ın Beyazıt civarındaki İranlı sahaflarda alenen basılması ile ilgili bir müfettiş raporu, ${ }^{74}$ satış yapılan muhtemel noktalardan biri olarak Şirket-i İraniye’nin o civardaki dükkânını akla getirmektedir. Şirket-i Hayriye-i Sahafiye’nin sahibi Hacı Hüseyin’in Şirket-i İraniye ile sıcak ilişkisi düşünüldügünde bu tür işbirliklerine gittiklerini düşünmek çok da yanıltıcı olmaz.

Bakırcılar Çarşısı karşısındaki dükkânı işleten Şirket-i Sahafiye hissedarlarından İsmail'in dükkânındaki Takvim-i Sâlin toplatırırılması ve bu işe karışanlar hakkında kanuni işlem başlatılması ile ilgili yazışmalar hem olayın ayrıntılarını hem de şirketin 'kaçak' olarak neler bastığına dair bilgimizi artırmaktadır. Validehan'daki Abbas Kerimov'un matbaasında [Şirket-i İraniye matbaası] basılmış "1322 sene-i Kamerî ve 1320 sene-i Malîsine mahsus Hüseyin Hüsnü mührüyle ve Takvim-i Sâl namıyla bila-ruhsat bir takvim” kitapçı dükkanında satışa sunulmuştur. Başlatılan incelemeler çerçevesinde Hacı Abbas'ın Valide Han'daki matbaası, Sultan Beyazıt

İ. Lütfü Seymen, "Erbab-1 Mütalaaya Hizmet: I. Meşrutiyet Kitapçılığı ve Arakel Tozluyan Efendi'nin Mektupları”, Müteferrika, 1(1993), s. 70.

71 Tugay, İbret, s. 129.

72 Tugay, İbret, s. 129-130.

73 BOA, MF. TTD 51/59, 5 Ramazan 1318/27 Aralık 1900.

74 BOA, DH. MDK 223/179, 29 Şaban 1312/ 25 Şubat 1895. 
civarında Bakırcılardaki kütüphane ve Sarnıçlı Han'daki deposu arandığında bulunan 2447 adet takvim bir sandık içine yerleştirilerek mühürlenmiştir. ${ }^{75}$

\section{Şirket-i Sahafiye-i İraniye'nin Dini Yayın Faaliyetleri}

Yayıncılık türlerinden biri olan dini yayıncılık, Osmanlı yazma ve matbu kitap tarihinde her dönem revaçta olmuştur. ${ }^{76}$ Bu bağlamda Ahmediye, Muhammediye, Envarul-Aşııîn gibi yayınlar, Şirket-i Sahafiye-i İraniye'nin popüler kitap neşretme politikasının en başından beri belirgin olduğuna işaret olarak değerlendirilebilir. Dini yayıncılığın önemli kalemlerinden birisi olan medrese ders kitapları sahasında da şirket etkin olmuştur. Bu bağlamda bastığı Kadı İyaz’n Sifa-i Şerifi kapak yazısında 'talebe-i uluma hizmet' gibi bir amacı zikretmesi hayli anlamlıdır. Bu ibare şirketin medrese talebelerine yönelik kitap piyasasında da varlık göstermek istediğini hissettirmektedir. Şifảnın yazıldığı günden beri İslam dünyasında büyük ilgi görmüş, üzerinde şerh, haşiye, ihtisar ve tercüme şeklinde pek çok çalışma yapılmış, medreselerde öğrencilere camilerde halka okutulmuş bir eser olduğu hatırlatılmalıdır. ${ }^{77}$ Şirketin çok satması muhtemel bu tür muteber dini eserler başta olmak üzere dini neşriyata ağırlık verdiği söylenebilir.

75 Bu konudaki yazışmalar için bkz. BOA, DH. MKT 830/90, 29 Zilhicce 1321/ 17 Mart 1904; BOA, MF. MKT 771/30, 9 Muharrem 1322/26 Mart 1904; BOA, DH. MKT 868/86, 26 Rebiülahir 1322/ 10 Temmuz 1904.

76 Sahafların ürettiği ve sattığı kitap türlerine ve dini kitapların bu durumdaki payına dair ayrıntılı bilgi için bkz. Erünsal, Osmanlılarda Sahaflık ve Sahaflar, s. 140, 152, 338, 340. "Sahaf-kitapç"ların hepisinin XIX. asrın ilk yarısında yayınladıkları eserler ticaretlerinin geleneksel çizgileriyle uyumludur. Asırlardır sattıkları dini ilimlerle ilgili eserler yanında halka yönelik birtakım kitaplar ve az da olsa bazı tarih kaynaklarını basmışlardır (Erünsal, Osmanlılarda Sahaflık ve Sahaflar, s. 89). Matbaanın aktif kullanıldı̆̆ı XIX. asrın ikinci yarısında faaliyetlerini İstanbul'da sürdüren Acem kitapçı Hacı Hüseyin Efendi'nin yayınladığı eserlerin yarısından fazlasını dini eserlerin oluşturması bu durumun başka bir delilidir. Şirket-i Hayriye-i Sahafiye'nin müdürü, Şirket-i Sahafiye-i İraniye’nin aktif bir üyesi olan Hacı Hüseyin'in kitapçılık serüveninde Mushaf basımı ve dini kitap yayıncılığı önemli bir yer tutmaktadır. Dığıroğlu, Dersaadette Bir Acem Kitapçı, s. 22, 36-43. Ayrıca II. Abdülhamid dönemi Mushaf basımı ve dini yayıncılığı hakkında ayrıntılı bilgi için bkz. Filiz Dı̆̆ıroğlu, "II. Abdülhamid Dönemi Matbûat Politikaları: Mushaf Basımı ve Dinî Neşriyat”, Sultan II. Abdülhamid Han ve Dönemi, ed. Halil İbrahim Erbay, Fahrettin Gün (Ankara: TBMM Basımevi, 2017), s. 631-651.

77 Kadı İyaz’ın (ö.544/1149) Peygamber sevgisine ve Hz. Peygamberin müslümanlar üzerindeki haklarına dair eseri olan eş-Şifa hakkında bkz. M. Yaşar Kandemir, "eş-Şifa”, Türkiye Diyanet Vakfi İlam Ansiklopedisi (DİA), 2010, XXXIX, s. 134-138. 
II. Abdülhamid dönemi ile birlikte kitap takiplerinin artması ve denetim mekanizmalarının daha profesyonelce işletilmesinden dini yayıncilık da etkilenmiştir. Bu alanda varlık göstermek isteyen Şirket-i İraniye de tüm Osmanlı kitapçıları/matbaacıları gibi söz konusu mekanizmalarla muhatap olmuştur. Bu bağlamda Şirket-i Sahafiye Müdürü Abbas Efendi’nin basmak istediği ZübdetülMesail ve'l-Akaid adlı Çağatayca risale, Şeyhülislamlıktaki "Tetkikât-ı Müellefât Heyeti”ne gönderilmiştir. Heyet tarafından basımı uygun görülen Çağatayca risaleye 6 Ekim 1891'de basım izni verilmiştir. ${ }^{78}$ Şirket-i İraniye Matbaası'nda Şeyh Muhyiddin Arabi hazretleri âsârından olup Türkçe'ye tercüme edilmiş olan Evrâd-ı Seb'a Şerhìni basmak istediğinde ise "tercüme bir hayli hatayı şamil" olduğu gerekçesiyle onay verilmemiştir. ${ }^{79}$ Nûniyye nam manzume ise heyet tarafından "...kıraat olunan mahallerinin ibare ve ifadesinde dahi pek çok hata ve noksan bulunduğundan dolayı tab'ı caiz olmadığı” şeklinde değerlendirilmiştir. ${ }^{80}$ Bu örneklerden de anlaşıldığı gibi Şirket müracaatları devlet makamlarından her daim rahatlıkla onay alamamıştır.

Şirket-i İraniye’nin II. Abdülhamid dönemi kitap denetleme mekanizmaları ile muhataplığına daha yakından bakmak, şirketin yayın politikalarını anlamamızı sağladığı gibi devletin şirket neşriyatına bakışını da görmemizi sağlar. 1892'de şirketin basmak istediği bir fikıh kitabı [Halebî Tercümesi Babadăğ̂̀] ile Çehâr Kitap ve Sebâtül-Âcizîn isimli kitaplar incelenmek üzere Şeyhülislamlıktaki "Tetkikât-1 Müellefât Heyeti”ne gönderilmiştir. ${ }^{81}$ Heyet, Haleb̂̀ Tercümesinnin hamişinde bulunan Tuhfe-i Şâhâne’nin ve Çehâr Kitap isimli kitaptan da ikinci kısmının çıkarılması halinde basılabileceğine ve Babadă̆̊̀ adlı eserin basılmasında bir mahzur olmadığına, Sebâtül-Âcizîn isimli kitabın da tekrar basılmasında sakınca olmadığına karar vermiştir. ${ }^{82}$ Şirket-i Sahafiye-i İraniye Müdürü Abbas Efendi'nin basım ve yayını için izin müracaatında bulunduğu Muhtasarül-Vikaye, Fıkh-ı Keydâni ve Şerh-i Akaid isimli kitaplar, incelenmek üzere Meşihat'teki komisyona gönderilmiştir. ${ }^{83}$ Bab-1 Fetva'daki komisyon üç

78 Meşihat Arşivi, Tedkîk-i Mesâhif ve Müellefât-1 Şer'iyye Dairesi Defterleri, 1784, s. 60. 79 Meşihat Arşivi, Tedkîk-i Mesâhif ve Müellefât-1 Şer'iyye Dairesi Defterleri, 1784, s. 61. 80 Meşihat Arşivi, Tedkîk-i Mesâhif ve Müellefât-1 Şer'iyye Dairesi Defterleri, 1784, s. 61.

81 BOA, MF. MKT 146/14, 2 Muharrem 310/ 27 Temmuz 1892.

$82 \mathrm{Bu}$ hususun Meşihat'teki meclis kararı için bkz. Meşihat Arşivi, Tedkîk-i Mesâhif ve Müellefât-1 Şer'iyye Dairesi Defterleri, 1784, s. 88; BOA, MF. TTD 24/106, 23 Rebiülahir 1310/14 Kasım 1892.

83 BOA, MF. MKT 138/21,11 Mart 1308/23 Mart 1892. 
kitabı değerlendirip "mezkur kitapların tab" ve neşirleri caiz olduğu” yönünde görüş beyan etmiştir. ${ }^{84}$

Görüldüğü üzere şirket yayın politikasına medreselerde okutulan ders kitaplarını almış ve devlet makamlarında baskı prosedürünü şirket namına müdür Abbas Kerimov yürütmüştür. Matbaacı Hacı Abbas tarafından baskı ruhsatı istenen Kırk Suali değerlendiren heyet "risale bir hayli hatayı şamil olduğu cihetle tekrar tab ve neşri caiz olmadığı” ifadeleriyle basım izni vermemiştir. Reddetme gerekçesinde kitabın baskı tekrarı için başvuruda bulunduğu ikinci baskısına onay alamadığı görülmektedir. ${ }^{85}$ Aynı yıl içerisinde Bab-1 Fetva'daki heyetin önüne Matbaacı Hacı Abbas ikinci defa basmak istediği Miftahu'l-Cenan ile gelir. Yapılan incelemede kitap hatalı bulunduğu için reddedilir. ${ }^{86}$ Kitapçı Abbas Efendi'nin baskı izni istediği Mecmuu'l-Adab risalesi de benzer gerekçelerle onay verilmeyen şirket başvurularından biri olarak tarihte yerini almıştır. ${ }^{87}$

Bir süre sonra baskı prosedürlerini Şirket-i Sahafiyye-i İraniye hissedarlarından İsmail Efendi'nin yaptığı gözlenmiştir. Yanlışları düzeltilerek baskı izni aldığı Enam-ı Şerif, ${ }^{88}$ tekrar baskısına izin verilen Mızraklı İlmihal, ${ }^{89}$ şirket hissedarlarından İsmail Efendi'nin baskı ruhsatı aldığı Müzekkin-Nüfus ${ }^{90}$ şirketin dini neşriyat politikası çerçevesinde değerlendirilmesi gereken yayınlarıdır. Talebelere yönelik neşriyat içerisinde addedilebilecek Sülüs Meşki risalesi de Şirket-i İraniye’ye baskı tekrarı izni verilen eserler arasında yerini almıştır. ${ }^{91}$

Şirket-i İraniye’nin gümrüklerde yakalanan bazı kitapların üzerinde alametlerinin görülmesi, ruhsatsız kitap basmaması hususunda daha önce uyarılmasına

84 Şirket-i sahafiye müdürü Abbas Efendi'nin söz konusu müracaatı 19 Zilkaade 1309/15 Haziran 1892'de değerlendirilmiştir. Meşihat Arşivi, Tedkîk-i Mesâhif ve Müellefât-1 Şer'iyye Dairesi Defterleri, 1784, s. 79.

85 Meşihat Arşivi, Tedkîk-i Mesâhif ve Müellefât-1 Şer'iyye Dairesi Defterleri, 1784, s. 163.

(23 Şaban 1314/27 Ocak 1897). Eserin ilk baskısı Validehan'daki şirket matbaasında 1290 yılında gerçekleşmiştir. Bkz. Ek 2.

86 Meşihat Arşivi, Tedkîk-i Mesâhif ve Müellefât-1 Şer'iyye Dairesi Defterleri, 1784, s. 169 (14 M 1315/15 Haziran 1897).

87 “...bir hayli hatayı şamil olduğu cihetle tab ve neşri caiz olmadığı...” Meşihat Arşivi, Tedkîk-i Mesâhif ve Müellefât-1 Şer'iyye Dairesi Defterleri, 1785, s. 10 (30 Zilkaade 1316/11 Nisan 1899).

88 BOA, MF. MKT 779/48, 27 Safer 1322/13 Mayıs 1904.

89 BOA, MF. MKT 786/95, 6 Rebiülahir 1322/ 20 Haziran 1904.

90 BOA, MF. MKT 799/8, 13 Cemaziyelahir 1322/ 25 Ağustos 1904.

91 BOA, MF. MKT 988/48, 18 Safer 1325/ 2 Nisan 1907. 
rağmen, kaçak baskılara devam ettiğini göstermektedir. Osmanlı makamları İran tebaasından olan bu matbaa sahiplerini Osmanlı matbuat kanunlarına uygun hareket etmeleri gerektiği konusunda uyarmak için İran sefaretine durumu tebliğ etmiştir. ${ }^{92}$ Aynı belgedeki bazı ifadeler Şirketin kitap kapaklarında şirket ismi vermeden de yayın yaptığına işaret etmektedir. Kapakta matbaa adı olmaksızın basılan bu tür kitaplar, şirketin kaçak baskılardan ceza almamasını sağlayan bir yöntem olmalıdır. Şirket-i Sahafiye-i İraniyye'nin bastığı İzhar Múribìye, Odesa’ya geçerken gümrükte ruhsatsız oldukları gerekçesi ile el konulması, şirketin oldukça karlı bir saha olan medrese ders kitapları alanında kaçak baskılara yöneldiğini gösterir. Ayrıca gümrükte Odesa’ya giden sandığın içerisinde Ahter Matbaası'nda basılmış ruhsatsız Yenabiül-Mevedde ile birlikte yakalanması da oldukça manidardır. ${ }^{93}$ Bu bilgiler Şirket başta olmak üzere İstanbul'daki İranî kitapçıların bastığı kitapların dolaşımını işaret etmesi bakımından anlamlıdır. Kırım tarafına doğru yola çıkan sandığın içerisindeki kitapların farklı ama çok yakın ilişkisi olan iki Acem matbaasına ait olması, benzer yollarla işletilen ilişkiler ağı ile yurt dışına ortak dağıtım yaptıklarını düşündürtmektedir.

Maarif Nezareti müfettişlerinin raporlarında Abbas'ın idare ettiği Şirket-i Sahafiye'de birçok yasak eser bulunduğuna dair bilgiler bulunmaktadır. Kanunsuz ve yasaklı yayınları satan İranlı kitapçılar arasında Şirket-i Sahafiye-i İraniye'nin özellikle zikredilmesi kaçak satışlara ara vermeden devam ettiğini göstermektedir. ${ }^{94}$ Yine yasaklı kitaplardan halkın çokca rağbet ettiği Şerhli Vasiyetname'nin Şirket-i Sahafiye-i İraniye'den çıkması, şirketin kaçak faaliyetlerini hız kesmeden sürdürdügünü göstermektedir. ${ }^{95}$ Müfettiş raporlarında Şirket-i Sahafiye-i İraniye'nin Müdürü Abbas Kerimov’un bu tür yasakları geceleri matbaasında bastığı ve matbaaların 'geceleri icra-yı sanattan men edilmeleri' gerektiği belirtilmiştir. ${ }^{96}$

92 BOA, MF. MKT 69/48, 19 Şevval 1298/14 Eylül 1881.

93 BOA, MF. TTD 49/92, 26 Zilhicce 1316/ 7 Mayıs 1899.

94 Burada kastedilen şirketle aynı isimdeki Beyazıt'taki kitapçı dükkanı olmalıdır. BOA, MF MKT 509/22 (19 Safer 1318/18 Haziran 1900).

95 Matbuat yasakları tarihinde az rastlanan hadiselerden biri, bazı neşriyatın hemen her devirde tartışmalara yol açması, hatta lanetlenmesi ve tabii yasaklanmış olmasıdır. Bu sahada en dikkate değer örneklerden biri Şeyh Abmet’in Vasiyetnamesi ismiyle tanınan risaledir. Bu konuda ayrıntılı bir çalışma için bkz. Ali Birinci, "Her Devirde Yasaklanan Bir Risale: 'Şeyh Ahmet'in Vasiyetnamesi'”, Tarih Yolunda Yakın Mazînin Siyasi ve Fikrî Ahvâli (İstanbul: Dergah Yayınları, 2001), s. 246-257.

96 BOA, DH MDK 247/52, 5 Cemaziyelahir 1320/9 Eylül 1902. 
Dini yayıncılığın önemli bölümlerinden biri de Osmanlı matbuatında Kelam-1 Kadim de denilen Mushaf-1 Şerif basımıdır. Matbu Kuran hakkında söylenmesi gereken ilk şey yazma nüshası her zaman için çok pahalı olan Kuran'ın matbu nüshalarının ilk basılanlardan itibaren büyük alaka gördüğü ve bu sahanın çok cazip bir kazanç alanı olduğudur. Osmanlı'da matbaacıllğın henüz bir mevzuata kavuşmamış olduğu 1850'li yıllarda ve öncesinde kayda geçmemiş ve ruhsat alınmamış birçok kitabın yanı sıra Kuran da basılmıştır. İstanbul'da ilk olarak İranlı kitapçılar da denen Azeri kitapçıların Kuran basma ve matbu Kuran satma işlerine giriştikleri bilinmektedir. ${ }^{97}$

Dersaadet neşriyat sektöründeki en etkili girişimlerden biri olan Şirket-i Sahafiye-i İraniye’nin matbu Mushaf işinde bir hayli gayretkeşlik gösteren Acem kitapçılardan geri durmadığını tahmin etmek güç değildir. İşte bu faaliyetleri neticesinde ortaya çıkan İranîlere ait kaçak Mushaf baskıları hem devlet makamlarında hem de Osmanlı basınında sık sık gündeme gelmekte ve sürekli eleştirilmekteydi. Bazen bu gündemlerin merkezinde yer alan Şirket-i Sahafiye-i İraniye müdürü basın yoluyla söz konusu eleştirilere cevap verme ihtiyacı hissetmiştir. Bu bağlamda İstanbul'da mukim İranlılar hakkında olumsuz yazılar yazan Mizan Gazetesi'ne cevap vermiştir. Şirket-i İraniye matbaası müdürü imzalı yazıda özellikle Validehan'da İranlı matbaacıların denetlenemediği iddiasına cevap verilmiştir. Teftiş heyetinden Ermeni Mihail Efendi'nin yanında bir polisle geldiği, kahvesini içtikten sonra İran sefaretinden bir memur bulunmamasına rağmen matbaayı teftiş ettiği ve basılan Kuran-1 Kerim nüshalarını gördüğü anlatılmış, Mushaf basımı ile ilgili imtiyazın kalktığı ve Meşihat'ten izin çıktığı vurgulanarak kanuna mugayir bir iş yapılmadığı dile getirilmiştir. ${ }^{98}$ Her ne kadar matbaa/şirket müdürü kendisi ve hemşehrisi Acemleri kaçak Mushaf meselesinde aklamaya çalışsa da ilerleyen yıllarda dükkânlarda görülen kaçak Mushafların birçoğu onları işaret etmekteydi. Örneğin Validehan'daki Şirket-i İraniye'de ruhsatsız basılan ve Çadırcılar'daki Acem mücellid Rıza’nın dükkânında yakalanan Mushaf'lara el konulmak istenmesi, ${ }^{99}$ Şirket-i

97 Türkiye'de Kur'ân basımının serüveni için bkz. M. Brett Wilson, Translating the Qur'an in an Age of Nationalism: Print Culture and Modern Islam in Turkey, (Oxford: Oxford University Press, 2014). [Türkçe çevirisi: Brett Wilson, Milliyetçilik Çă̆ında Kuran Tercümeleri: Türkiye'de Yazılı Kültür ve Modern İslam, çev. Ceren Can Aydın, (İstanbul: Alfa Basım, 2018). Ali Birinci, "Osman Bey ve Matbaası Ser-kurenâ Osman Bey’in Hikâyesine ve Matbaa-i Osmaniye'nin Tarihçesine Medhal”, Müteferrika, 39 (2011), (Ayrı Basım), s. 23-43.

98 Abter, XV/I, 1306, s. 4-5'ten naklen Yıldız, "İstanbul'da Bir Acem Matbaası", s. 188, dn. 62. 99 BOA, MF. MKT 147/69, 16 Muharrem 1310/ 10 Ağustos 1892. 
İraniye matbaasındaki ruhsatsız Mushaflar sebebiyle matbaanın kapatılıp, Mushafların müsadere edilmesi, ${ }^{100}$ izinsiz Mushaf basıldığı bildirilen Validehan'daki Şirket-i Sahafiye-i İraniye Matbaası'nda yapılan incelemede birşey bulunamadığı ${ }^{101}$ gibi kayıtlara bol miktarda rastlanması bu sorunun devam ettiğini göstermektedir. Validehan'da Şirket-i İraniye’nin de içinde bulunduğu bazı mahallerde ruhsatsız basılmış mesahif-i şerifenin müsaderesi için giden memurlar, "Validehan'ı mecmu-1 İraniyan" olduğundan türlü zorluklarla karşılaşmışlardır. ${ }^{102}$ Teftiş ve muayenede karşılaştıkları zorlukların başında İranlı matbaacı/kitapçı esnafının dükkânlarını aratmak istememeleri, karşı koymaları ve sefaretten bir memur olmazsa herhangi bir işlem yaptırmamaları gelmektedir. İşte Şirket-i İraniye müdürü birkaç sene evvel yaptığı yazılı açıklamada bu tür iddiaları reddetse de işlerin her zaman onun anlattığı gibi kanuni çerçevede yürümediği açıktır.

\section{Sonuç}

Şirket-i Sahafiye-i İraniye, İstanbul matbuat tarihinin son derece hareketli olduğu XIX. yüzyılın üçüncü çeyreğinde faaliyetlerine başlamıştır. Faaliyetlerini Validehan merkezli yürüten şirketin, mekânsal varlık alanları handaki matbaası, Beyazıt'taki kitapçı dükkânı ve yine başka bir handaki deposudur. Acem sermayesi ile kurulan şirketin İranlılar dışında bir ortağı henüz tespit edilememiş olsa da Acemler dışında çalışanları olduğu görülmüştür. İstanbul'da meslek örgütlenmesi ve işletme biçimi açısından Şirket-i Sahafiye-i İraniye diğer kitapçlara örnek olmuştur. Şirket'in matbaası sayesinde yayıncı, kitapçısı sayesinde hem kendi kitaplarını hem de İstanbul piyasasındaki diğer kitapları temin eden bir naşir gibi çalıştığı görülmektedir. Bu çalışma tarzı son dönem Osmanlı matbuat hayatında matbaa sahibi yayıncılar için olağan bir durum sayılabilir. Şirketin esasen İstanbul okur piyasasına ve Osmanlı coğrafyasına yönelik yayınlar yaptığı görülmüştür. Ancak basım izni aldığı Çağatayca risale ya da bastığı bazı kitapların arkasına koyduğu ilanlar Türkistan coğrafyasına dönük bir neşriyat politikasını benimsediğini göstermektedir. Söz konusu ilanlar şirketin hedef kitlesini ve çalışma biçimini gösterdiği gibi İstanbul merkezli yayıncılı̆̆ın uluslararası boyutlarını da göstermektedir. Nitekim Şirket-i İraniye'nin Buhara ve Taşkent'te şube açması ve hatta oradan gelecek talepleri İstanbul'da titizlikle basabileceği vaadi kitap trafiğinin

100 BOA, DH. MDK 220/169, 5 Rebiülahir 1310/27 Eylül 1892.

101 BOA, MF. MKT 300/17, 19 Receb 1313/ 5 Ocak 1896.

102 BOA, DH. MDK 220/171, 6 Rebiülahir 1310/28 Eylül 1892. 
boyutlarına dair bir fikir vermektedir. Benzer şekilde Kırım coğrafyasına giden bir kasadan çıkan Şirket-i İraniye menşeli kitaplar ya da Mısır'dan gelen kitap paketinin adresinin Şirket-i İraniye matbaası olması kitap dolaşımının ülke sınırlarını aştığını bir kez daha ortaya koymaktadır.

Şirket-i Sahafiye-i İraniye'nin her ne kadar ilk baskısı dikkat çekici bir biçimde Şia kelamına dair bir eser olsa da yayın serüveninde bu tavrını sürdürmediği gözlenmiştir. Edebî, tasavvufî kitaplardan Farsça, İngilizce lugatlara, Fransızca uyarlamalardan medrese ders kitaplarına, halk hikayelerinden dini kitaplara kadar oldukça geniş bir yelpazede yayın yapmıştır. Osmanlı okurunu hedefleyen yayın politikasının ağırlığını her zaman çok satan ve revaçta olan kitapların oluşturduğu aşikardır. Muhammediye, Ahmediye ve Envarul-A̧şıkin ya da İlmihal türündeki kitaplar bu bağlamdaki yayınlara güzel örnektir. Mushaf başta olmak üzere sık sık kaçak baskılar ile gündeme gelen şirket bu tavrından faal olduğu sürece vazgeçmemiştir. Aynı şekilde yasaklı kitapların da şirketin çeyrek asırlık yayın pörtföyünde rahatlıkla yer aldığı görülmüştür. Kaçak baskıların resmi prosedürle uğraşmadan pratik ve kârlı ancak daha riskli bir yol olduğu düşünüldüğünde şirketin her şeyi göze alarak korsan baskıya devam etmesi ancak vaadettiği ticari kazançla açıklanabilir.

Öz —XIX. yüzyılın ikinci yarısında Osmanlı'da matbaacilığın yaygınlaşması ile birlikte özel matbaaların sayısı hızla artmış ve Osmanlı matbuat piyasasında birçok aktör devreye girmiştir. Bu aktörler içerisinde 'Acem basmacılar/kitapçılar' da denen İranlı müteşebbislerin önemi inkar edilemez bir gerçekliktir. Acem kitapçların da içinde bulunduğu Osmanlı matbuat piyasasında bazı matbaacı ve kitapçılar güçlerini birleştirerek şirketleşmeye gitmiştir. Bu makaleye konu olan Şirket-i Sahafiye-i İraniye, Osmanlı yayıncılık tarihinde söz konusu şirketlere öncülük etmesi ve İstanbul'da yaşayan İranlı/Acem matbaacı/sahaf esnafı tarafından kurulması bakımından diğerlerinden ayrılmaktadır. İstanbul'da faaliyet gösteren Acem/İranî matbaacıların daha ucuz neşriyat yapmak amacıyla bir araya gelerek kurdukları Şirket-i Sahafiye-i İraniye, Osmanlı matbuatında yaklaşık çeyrek asılık bir döneme damgasını vurmuştur. Bu makale, şu ana kadar hakkında müstakil bir çalışma yapılmamış olan Şirket-i Sahafiye-i İraniye'nin kuruluşu, kurucuların ve ortakların kimlikleri ile meslekleri, matbaanın yeri, kitap satış noktaları, şirketin faaliyetleri, ne tür eserler bastı̆̆ı, yayın politikası, okur profili gibi noktaları ve şirketin Osmanlı resmi makamları ile ilişkilerini aydınlatmayı amaçlamaktadır. Osmanlı yayıncılığının gözle görülür bir ivme kazandığı II. Abdülhamid devrinde, Şirket-i Sahafiye-i İraniye'nin dönemin 'sansür' mekanizmalarıyla ilişkilerine özellikle değinilmiştir. Ayrıca şirket kurucularının 'Acem' kimliğinin yayın politikasında bir izdüşümü olup olmadığı tespit edilmeye çalışılmıştır.

Anahtar kelimeler: Osmanlı, Acem/İranlı, matbaa, şirket-i sahafiye, kitapçı. 


\section{Ek 1}

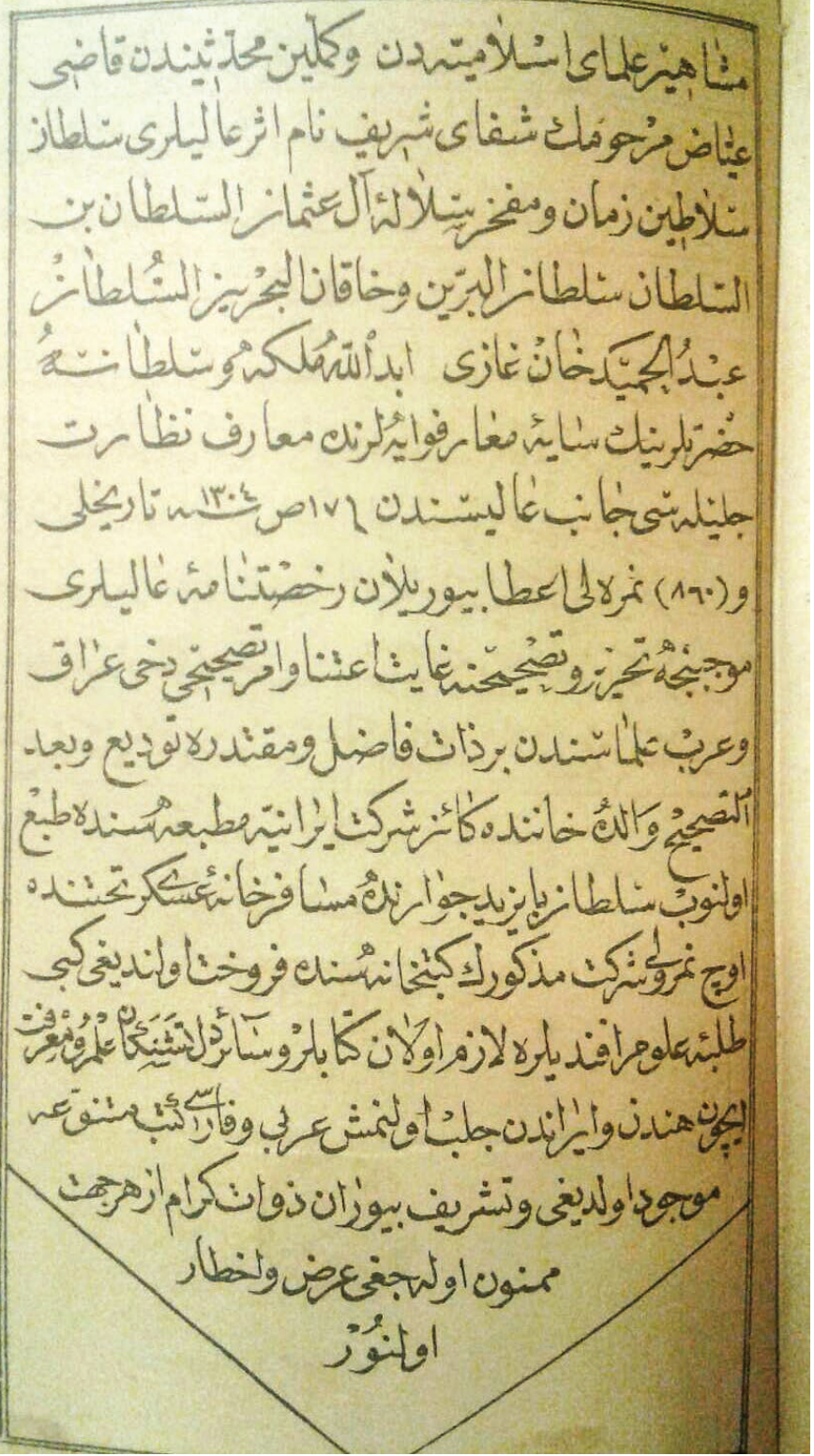

Şirket-i Sahafiye-i İraniye baskısı Şifa-i Şerifin arkasında yer alan ilandır. 
Ek 2

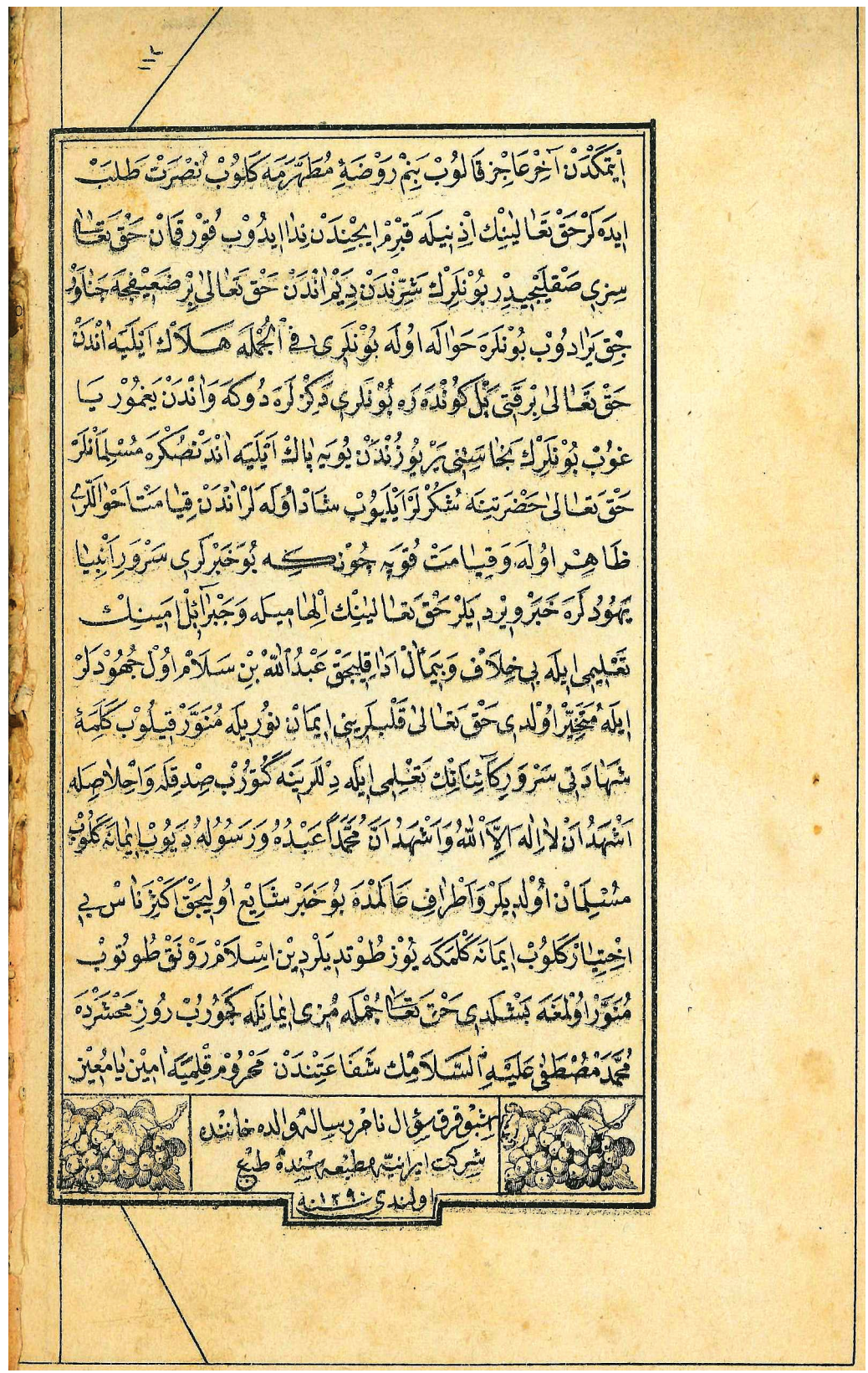

Kırk Sual, 1290, Şirket-i İraniye Matbaası. 


\section{Ek 3}

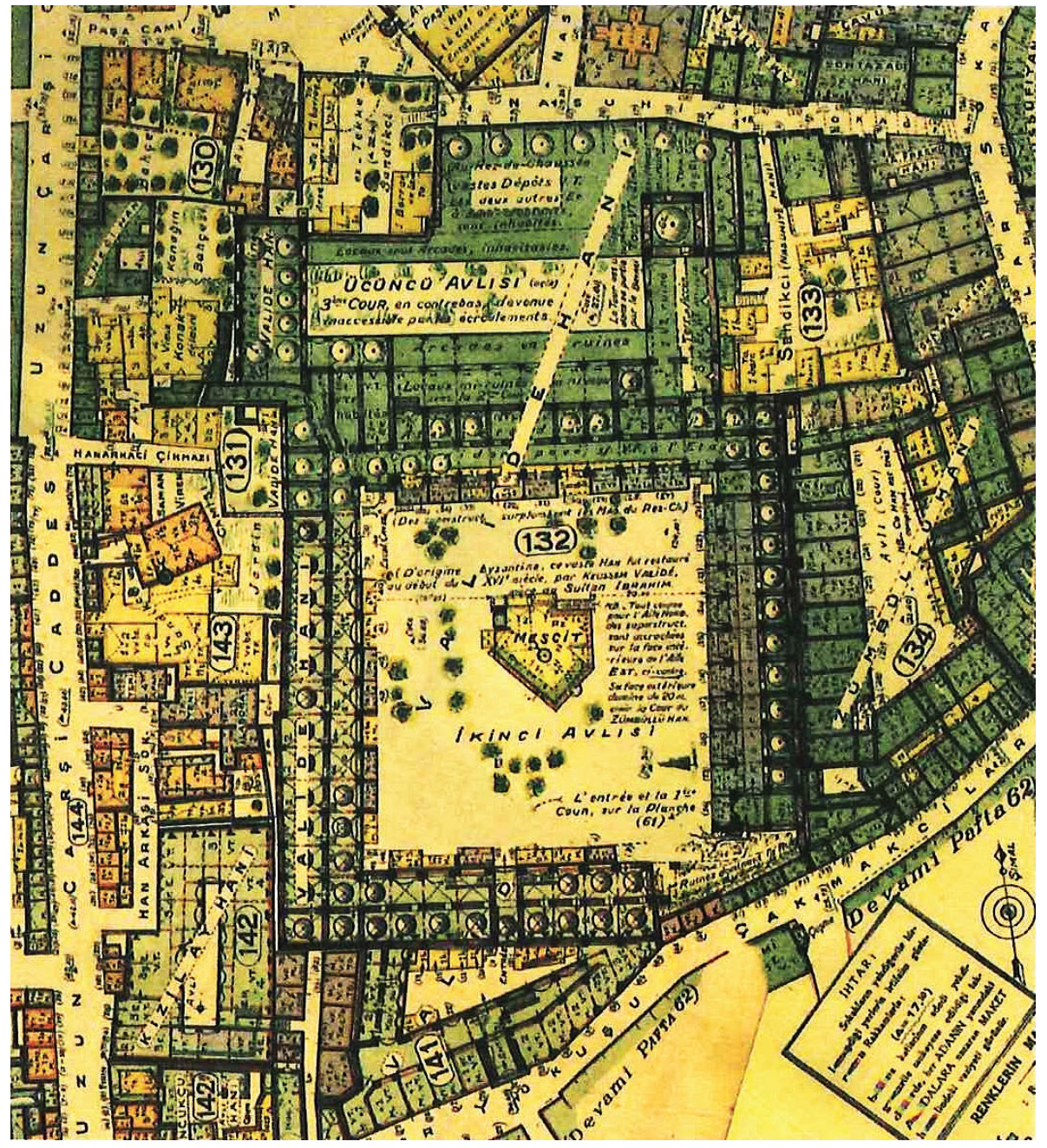

Çakmakçılar yokuşunda bulunan Validehan’ın planı. 


\section{Ek 4}

CORNELIUS GURLITT, ISTANBUL'UN MIMARI SANATI / ARCHITECTURE OF CONSTANTINOPLE / DIE BAUKUNST KONSTANTINOP
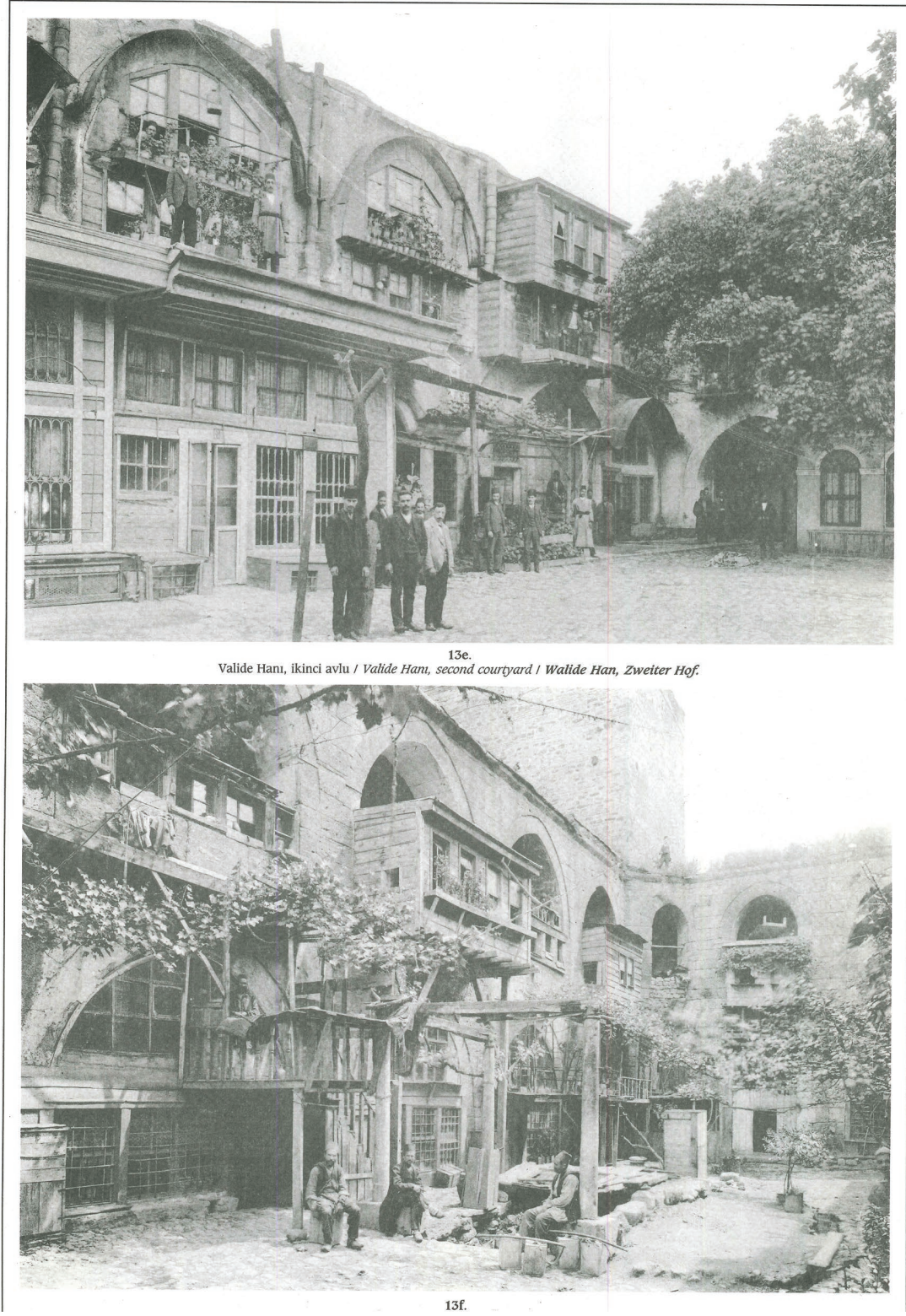

Şirket-i Sahafiye-i İraniye matbaasının yer aldığı Validehan'ın iç avlu görüntüleridir. Cornelius Gurlitt, İstanbul'un Mimari Sanatı, 1999. 


\section{Bibliyografya}

\section{Arşiv Belgeleri}

Türkiye Cumhuriyeti Cumhurbaşkanlığı Devlet Arşivleri Başkanlığı Osmanlı Arşivi (BOA)

BOA, Dahiliye Nezareti Matbuat-1 Dahiliye Kalemi (DH. MDK) 220/169, 220/171, 220/88, 223/179, 247/52, 278/98.

BOA, Dahiliye Nezareti Mektubi Kalemi (DH. MKT) 830/90, 868/86, 927/55, 1120/55, $1987 / 82$.

BOA, Maarif Nezareti Mektubi Kalemi (MF. MKT) 8/55, 9/57, 69/48, 79/18, 138/21, 146/14, 147/69, 300/17, 509/22, 657/52, 771/30, 786/95, 779/48, 799/8, 988/48, $1083 / 31$.

BOA, Maarif Nezareti Telif ve Tercüme Dairesi (MF. TTD) 22/74, 24/43, 24/57, 24/106, 49/92, 51/59.

BOA, Şura-yı Devlet (ŞD), 2970/31.

BOA, Zabtiye Nezareti (ZB) 20/25, 319/23, 320/88.

Meşihat Arşivi,

Tedkîk-i Mesâhif ve Müellefât-1 Şer iyye Dairesi Defterleri 1784, 1785.

\section{Yayınlanmış Eserler}

Abdullah b. Eşref Rumi el-İzniki: Müzekkiyün-nüfus, II, İstanbul: İrâniye Matbaası.

Alkan, Mehmet Ö.: "Osmanlı’nın Bütün Sahafları Birleşiniz! Şirket-i Sahafiye-i Osmaniye: Osmanlı Döneminde Sahaflar ve Yayınladıkları Kitaplar”, Müteferrika, 29 (İstanbul 2006), s. 3-44.

Baylav, Naşid: İlk Türk Kitap̧̧ılarından Hacı Kasım Efendi (1862-1962), İstanbul: Ten Tip ve Eczacılık Neşriyatı 1962.

Birinci, Ali: "Her Devirde Yasaklanan Bir Risale: 'Şeyh Ahmet'in Vasiyetnamesi', Tarih Yolunda Yakın Mazînin Siyasi ve Fikrî Ahvâli, İstanbul: Dergah Yayınları 2001.

Birinci, Ali: "Osman Bey ve Matbaası Ser-kurenâ Osman Bey'in Hikâyesine ve Matbaa-i Osmaniye'nin Tarihçesine Medhal”, Müteferrika, 39 (İstanbul 2011), (Ayrı Basım).

Bursalı Mehmed Tahir: Osmanlı Müellifleri, III, haz. M. Ali Yekta Saraç, Ankara: TÜBA Yayınları 2016.

Demirel, Fatmagül: “Osmanlı'da Bir Kitap Şirketi: Şirket-i Sahafiye-i Osmaniye”, Müteferrika, 25 (İstanbul 2004), s. 89-97. 
Dığıroğlu, Filiz: "II. Abdülhamid Dönemi Matbûat Politikaları: Mushaf Basımı ve Dinî Neşriyat”, Sultan II. Abdülhamid Han ve Dönemi, ed. Halil İbrahim Erbay, Fahrettin Gün, Ankara: TBMM Basımevi 2017, s. 631-651.

Dığıroğlu, Filiz: "İstanbul-Tebriz Ticaret Hattında Validehan (XIX-XX. Yüzyıl)", Türk Kültürü İncelemeleri Dergisi, 31 (İstanbul 2014), s. 69-112.

Dı̆̆ıroğlu, Filiz: Dersaadet’te Bir Acem Kitapçı: "Kitapfüruş Hacı Hüseyin Ağa", İstanbul: Turkuaz Yayıncılık 2014.

Ergin, Osman Nuri, Türkiye Maarif Tarihi, III, İstanbul: Eser Neşriyat 1977.

Erünsal, İsmail E.: Osmanlılarda Sahaflık ve Sahaflar, İstanbul: Timaş Yayınları 2014. Farş̧a Matbu Eserler Kataloğu (Osmanlıdan Günümüze), haz. Mustafa Çiçekler, (t.y.).

Fortna, Benjamin: Geç Osmanlı ve Erken Cumburiyet Dönemlerinde Okumayı Öğrenmek, çev. Mehmet Beşikçi, İstanbul: Koç Üniversitesi Yayınları 2013.

İlm-i Hâl, İstanbul: İraniye Matbaası 1304.

İstanbul Belediye Kütüphanesi Alfabetik Kataloğu, I, Osman Nuri Ergin Kitapları Arapça ve Farş̧a Basma Eserler, haz. M. Orhan Durusoy, İstanbul: İstanbul Belediye Kütüphanesi 1953.

Kadı İyaz b. Musa: eş-Şifa Bi-Tárifi Hukuki'l-Mustafa, İstanbul t.y.

Kandemir, M. Yaşar: "eş-Şifa", Türkiye Diyanet Vakfı İslam Ansiklopedisi (DİA), 2010, XXXIX, s. 134-138.

Les Iraniens d'Istanbul, eds. Thierry Zarcone, F. Zarinebaf-Shahr, Paris-Tahran-Istanbul: Institut Français de Recherche en Iran 1993.

Maarif Salnamesi, Dersaadet: Matbaa-i Amire 1316.

Maarif Salnamesi, Dersaadet: Matbaa-i Amire 1318.

Niya, Rahim Reis: İran ve Osmanî der Asitane-i Karn-ı Bistom, I, Tahran: Neşr-i Mebna; Tebriz: İntişarat-1 Setude 1328.

Özege, M. Seyfettin: Eski Harflerle Basılmış Türkçe Eserler Kataloğu, I-V, İstanbul: Fatih Yayınevi Matbaası 1971-1982.

Öztürk, Zehra: "Osmanlı Döneminde Kıraat Meclislerinde Okunan Halk Kitapları”, TALID, V, 9 (İstanbul 2007), s. 401-445.

Özyıldırım, Ali Emre: “İstanbul'da Basılıp Orta Asyåda Satılan Kitaplar ve Şeyh Süleyman Efendi ile Tâcir-i Kütüb Sıddık Hoca Hocendînnin Faaliyetleri”, Müteferrika, 54 (İstanbul 2018), s. 75-116.

Sebatül-Acizin, İstanbul: Matbaa-i Şirket-i İraniye 1310.

Sebatül-Acizin, İstanbul: Matbaa-i Şirket-i İraniye 1311.

Seymen, İ. Lütfü: "Erbab-1 Mütalaaya Hizmet: I. Meşrutiyet Kitapçıllğı ve Arakel Tozluyan Efendi'nin Mektupları”, Müteferrika, 1 (İstanbul 1993), s. 67-111. 
Strauss, Johann: "Osmanlı İmparatorluğu'nda Kimler, Neleri Okurdu? (19.-20.Yüzyıllar)", Tanzimat ve Edebiyat Osmanl İstanbuluinda Modern Edebi Kültür, haz. Mehmet Fatih Uslu, Fatih Altuğ, İstanbul: Türkiye İş Bankası Kültür Yayınları 2014, s. 3-64.

Tugay, Asaf: İbret: Abdülhamid'e verilen Jurnaller ve Jurnalciler, İstanbul: Okat Yayınevi 1962.

Wilson, M. Brett: Translating the Qur'an in an Age of Nationalism: Print Culture and Modern Islam in Turkey, Oxford: Oxford University Press 2014. [Türkçe çevirisi: Brett Wilson, Milliyetçilik Çağında Kuran Tercümeleri: Türkiye'de Yazılı Kültür ve Modern İslam, çev. Ceren Can Aydın, İstanbul: Alfa Basım 2018.

Yıldız, Güllü: "İstanbul'da Bir Acem Matbaası: Kitapçı Tahir ve Ahter”, Osmanlı Araştırmalar, 50 (İstanbul 2017), s. 175-218. 